\title{
Effects of the German Renewable Energy Sources Act and environmental, social and economic factors on biogas plant adoption and agricultural land use change
}

\author{
Xueqing Yang ${ }^{1 *} \mathbb{D}$, Yang Liư ${ }^{2,4}$, Daniela Thrän ${ }^{1,3}$, Alberto Bezama $^{1}$ and Mei Wang ${ }^{4}$
}

\begin{abstract}
Background: The German energy transition strategy calls for a reform of the German energy sector. As a result, the German Renewable Energy Sources Act (EEG) passed in 2000 is widely regarded as successful legislation for promoting bioenergy development. More than 1000 biogas plants were constructed in Central Germany (CG) between 2000 and 2014. Despite this, few studies have been conducted for this period, which systematically investigate how environmental, social and economic factors, as well as various EEG amendments have impacted biogas production or what the environmental consequences of biogas production development in CG have been.
\end{abstract}

Methods: The impacts of environmental, social and economic factors and different EEG amendments on biogas production decisions in CG were quantified using a multivariate linear regression model and the event study econometric technique. A GIS-based spatial analysis was also conducted to provide insight into the changes to agricultural land use that resulted from the development of biogas plants during the EEG period.

Results: The main finding was that the income diversification effect resulting from biogas production was the most important factor in a farmer's decision to adopt biogas production. In addition, all of the EEG amendments had a significant influence on the adoption of biogas production; however, EEG III and IV, which tried to promote small-scale plants, were unable to reduce the average size of the plants constructed in these two amendment periods. From a landscape perspective, there was a striking increase in the cultivation of silage maize in CG from 2000 to 2014. Silage maize was intensively cultivated in regions with a high installed biogas plant capacity. Since the first EEG amendment, permanent grassland area slightly increased while arable land area declined in CG.

Conclusions: The adoption of biogas production in CG was strongly driven by economic incentives for the farmers, more precisely, by the incentive to diversify their income sources. In addition to increase the subsidy, future EEG amendments should find new measures to encourage the adoption of small-scale biogas plants, which had been unsuccessful in EEG amendments III and IV.

Keywords: Biogas plant, Event study, Renewable Energy Sources Act, Behavior finance, Land use change

\footnotetext{
*Correspondence: xueqing.yang@ufz.de

1 Department of Bioenergy, Helmholtz-Centre for Environmental

Research (UFZ), Permoserstrasse 15, 04318 Leipzig, Germany

Full list of author information is available at the end of the article
}

\section{Background}

The 2015 United Nations Climate Change Conference in Paris is widely regarded as a critical step towards international solidarity in addressing climate change. According to the Paris Climate Agreement reached at that meeting, give appropriate credit to the original author(s) and the source, provide a link to the Creative Commons licence, and indicate if changes were made. The images or other third party material in this article are included in the article's Creative Commons licence, unless indicated otherwise in a credit line to the material. If material is not included in the article's Creative Commons licence and your intended use is not permitted by statutory regulation or exceeds the permitted use, you will need to obtain permission directly from the copyright holder. To view a copy of this licence, visit http://creativecommons.org/licenses/by/4.0/. The Creative Commons Public Domain Dedication waiver (http://creativecommons.org/publicdomain/zero/1.0/) applies to the data made available in this article, unless otherwise stated in a credit line to the data. 
it is now compulsory for countries to reduce greenhouse gas (GHG) emissions in order to limit global warming to less than $2^{\circ} \mathrm{C}$ above the pre-industrial average [1]. Germany has committed to reducing its GHG emissions by $14 \%$ relative to the 2005 levels by 2020 [2]. In 2016, the German government set out new goals in its Climate Action Plan 2050, which aim to reduce GHG emissions by at least $55 \%$ by $2030,70 \%$ by 2040 , and $80-95 \%$ by 2050 compared to the 1990 levels [3]. Given that around two-thirds of GHG emissions come from energy production and utilization, a transition from fossil fuels to lowcarbon solutions could have played a vital role in climate change mitigation [4]. The German energy transition strategy (German: Energiewende) focuses on a nuclear phase-out, reduction in fossil fuels and a sustainable promotion of renewable energies [5]. Major efforts towards reaching these goals have made Germany a pioneer in the energy reform sector and a leader of the broader worldwide energy transition [6, 7].

In Germany, the central instrument for promoting renewable energy is the Renewable Energy Sources Act (German: Erneuerbare Energien Gesetz, or "EEG"). The principal founder of this law is German parliamentarian Hans-Josef Fell of the Bündnis 90/Die Grünen faction, who drafted a key issues paper for the Green faction in early 1999. After his faction had adopted the draft paper, talks began with the Social Democratic Party (SPD) faction. Hermann Scheer of the SPD was the primary supporter and advocator of the proposed measures. After the SPD reviewed the bill in September 1999, it was sent to Germany's Federal parliament, the Bundestag. With the support of the SPD, the bill was adopted by the Bundestag on February 25, 2000 and come into effect on April 1, 2000 [8]. The overarching goal of the EEG is to promote electricity generation from different types of renewable energy so that the share of renewables in Germany's electricity consumption is at least $30 \%$ by 2020 [9-11]. One segment of the EEG policy focuses on the promotion of bioenergy production, which has been widely considered to be a significant contributor to global renewable energy production [12]. The EEG's ability to promote biogas production has been deemed successful. Between 2000 and 2017, the number of biogas plants in Germany has increased from 850 to 9,331 , with a cumulative installed capacity rising from 50 to $4800 \mathrm{MW} / \mathrm{h}$ [13-15]. In 2017 , the proportion of renewable energies in the total gross electricity generation in Germany reached 34\%, of which the share of biomass amounted to $23.42 \%$ [11].

The German biogas sector could have been divided into four phases of market and legislative development [15] (see Fig. 1). In light of the feedback following the introductory phase of the EEG as well as environmental issues and the availability of new bioenergy technology, the EEG was revised in 2004, 2009, 2012, 2014 and 2017 with subsidy modifications [16-21] (Appendix Table 6). Starting with the 2009 EEG amendment, the subsidy for small-scale plants has risen to promote the adoption of this type of biogas plant, as the large-scale biogas plants have caused several problems, such as a threat to food production, soil health and natural resources conservation [22-24]. Furthermore, upgrades in bioenergy technology resulted in a significant widening of the scope of the subsidy in the EEG 2009 amendment. Various new premium categories, such as manure, landscape material and emission reduction, were included in the remuneration scheme [18]. In the 2012 version of the EEG, a socalled "maize cap" was introduced to suppress the rapidly increasing cultivation area of maize and to increase the diversity of the crops grown for energy production [19, 25]. The EEG 2014 represented a paradigm shift for German biogas plants. It made major cuts in the subsidies associated with biogas plants, particularly for agricultural plants fueled by energy crops [20]. In 2017, the newly amended EEG introduced a tendering system to select

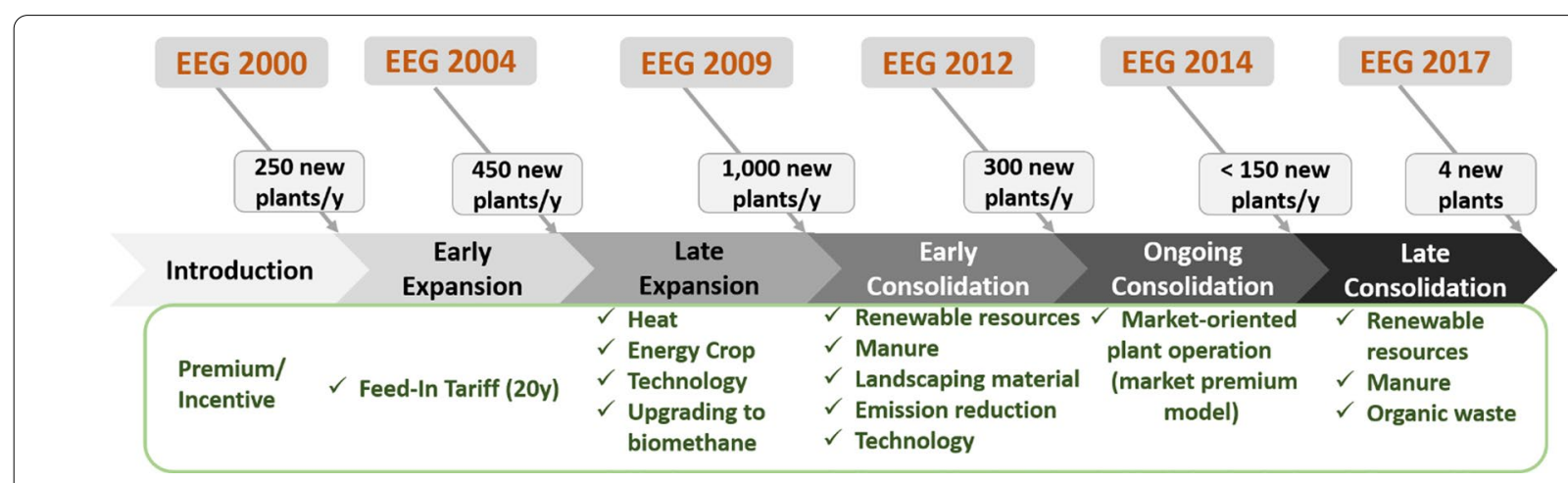

Fig. 1 The development phases of the German biogas sector along the timeline of the Renewable Energy Sources Act. Source: Thrän et al. (2020) 
renewable electricity producers. It established expansion corridors and volumes for auctioning renewable energy.

The EEG's primary measure for promoting biogas production is to provide subsidies to biogas plant operators [15, 26, 27]. Apart from these financial incentives, the decision to adopt a biogas plant is also influenced by several environmental, social and economic factors, which have been systematically examined in previous studies [28-32]. For example, the availability of feedstock was identified as having a strong influence on a farmer's decision to adopt biogas technology [33-38]. In Germany, there is a large concentration of biogas plants in regions with high livestock densities [30]. In terms of social factors, the farmers' education level plays a vital role in the adoption of biogas plants with respect to their ability to foresee the benefits and to operate the biogas plant $[35,37,39,40]$. Closely connected to education level, the farmer's awareness of renewable energy technologies also has a strong influence on whether biogas production is adopted [41, 42]. In addition, there is a correlation between the environmental protection awareness of local residents and the adoption of renewable energy technologies [43-46]. Furthermore, local political governance is also regarded as an important factor in the implementation of renewable energy policies at a local level $[47,48]$. In terms of economic factors, the income of local farmers is a determining factor involved in the decision to take up biogas production [33-38]. Finally, land for biomass cultivation and biogas plant construction positively correlates with the adoption of biogas technology [37, $38,49]$.

The current study aims to both empirically and spatially analyzing: (1) the effects of environmental, social and economic factors on biogas production decisions at a county level in Central Germany (CG); (2) the impacts of EEG 2000, EEG 2004, EEG 2009 and EEG 2012 (EEG I, EEG II, EEG III and EEG IV, respectively) on biogas production decisions and agricultural land use change in CG. The flowchart of the current study is presented in Fig. 2. There are many differences between our study and previous studies. Our study investigates the effects of environmental, social and economic factors and different EEG amendments on both the decision to adopt biogas production and the size of the plant. In addition, county-level data are used in our research to study a greater area. Furthermore, we linked the empirical analysis with the spatial analysis to study the impact of the EEG and other factors on the adoption of biogas production. Finally, we attempted to introduce the event study econometric technique in the environmentally relevant policy impact study to quantitatively analyze the effect of each EEG amendment on biogas production decisions [50-52].

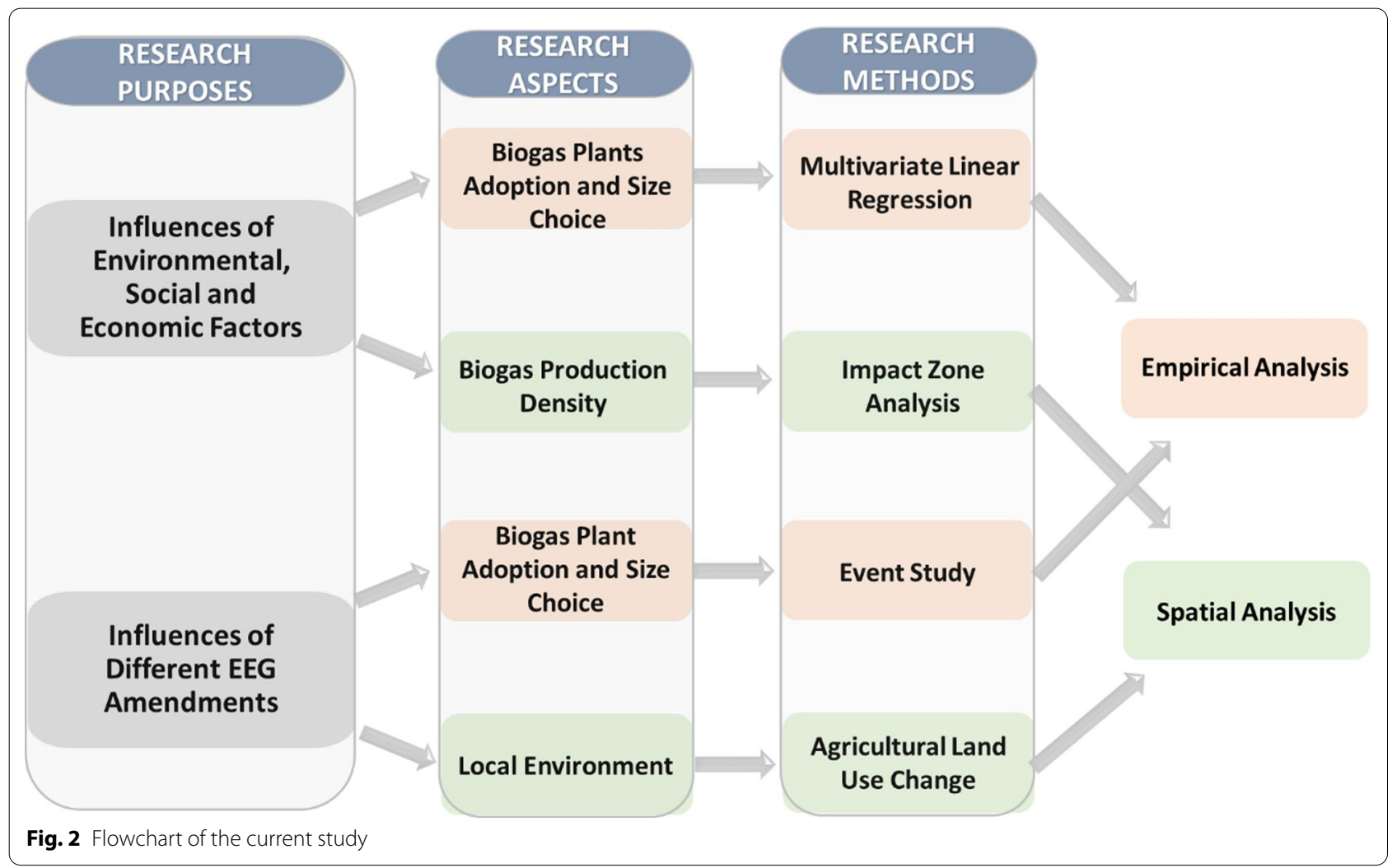




\section{Methods and data}

\section{Study site}

Central Germany includes the federal states of Saxony, Saxony-Anhalt and Thuringia (see Fig. 3). The total administrative area is approximately $55,105 \mathrm{~km}^{2}$ with Saxony comprising $18,450 \mathrm{~km}^{2}$, Saxony-Anhalt 20,454 $\mathrm{km}^{2}$ and Thuringia $16,201 \mathrm{~km}^{2}$ of the total area [53]. After several local government reorganizations, there are now a total of 50 counties (German: Landkreis and Kreisfreie Stadt) in CG. In 2018, the largest land use type was arable land which, at around $23,073 \mathrm{~km}^{2}$, made up about $42 \%$ of the total CG area. Wheat was the dominant crop among all the crops in this region. It was cultivated on around $33 \%$ of the total arable land. The cultivation areas of rapeseed, barley and silage maize made up $17 \%, 14 \%$ and $11 \%$ of the total arable land in CG, respectively. Other crops, such as rye, triticale and sugar beet, were also cultivated in CG. In addition to this, the total area of permanent grassland with its three types of utilization (i.e., mowing pastures, pastures and meadows) comprised $5,485 \mathrm{~km}^{2}$ or about $10 \%$ of the total CG administrative area [53].

\section{Method and data for empirical analysis General information on event study methodology}

We used the event study econometric technique to quantify the influences of different EEG amendments on biogas production decisions in CG. This method was originally designed to be used in the corporate finance research [54]. Among the different approaches for conducting an event study analysis, our study used the technique of multivariate regression with a dummy variable, which was suggested by Gibbons [50] and first implemented by Binder $[51,55,56]$. This technique is especially suitable for eliciting the magnitude of the effect of a regulatory event on a studied object [55]. Unlike other studies that use costly survey data to study policy effectiveness, the event study method only requires time series or panel data collected from databases which are bias free, i.e., selection bias and survivor bias [57]. Finally, by controlling other influential factors, this econometric method enables policy effects to be clearly differentiated from other effects.

The multivariate regression with dummy variable approach relies on the traditional $t$-test statistic; the dummy variables in this model are time dummy variables that represent events [58]. In each regression equation, the time dummy variable takes the value of 1 on the event date and otherwise 0 . The system of all regression equations can be estimated jointly as a multivariate regression model with dummy variables where, in the sample regression equation system below, the explanatory variables in the process ( $X$ and $Z$ ) are each an $n$th of the dependent variable $(Y)$, and the time dummy variable (TD) indicates the individual event date for each $n$th of the dependent variable $(Y)$ during the entire period under examination, from $t$ to $t+m$ : a

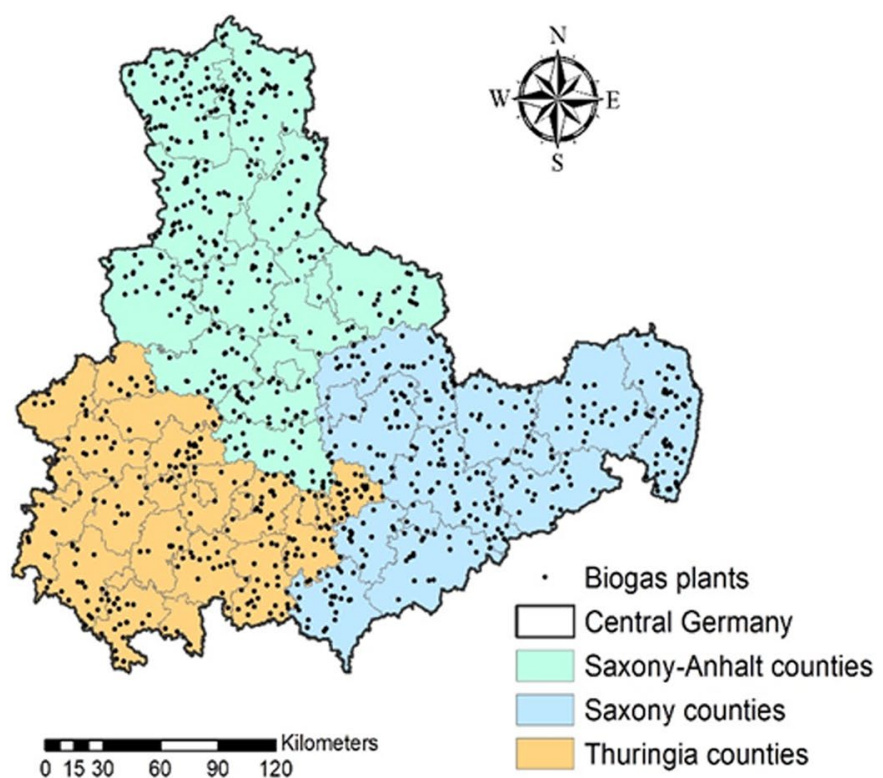

b

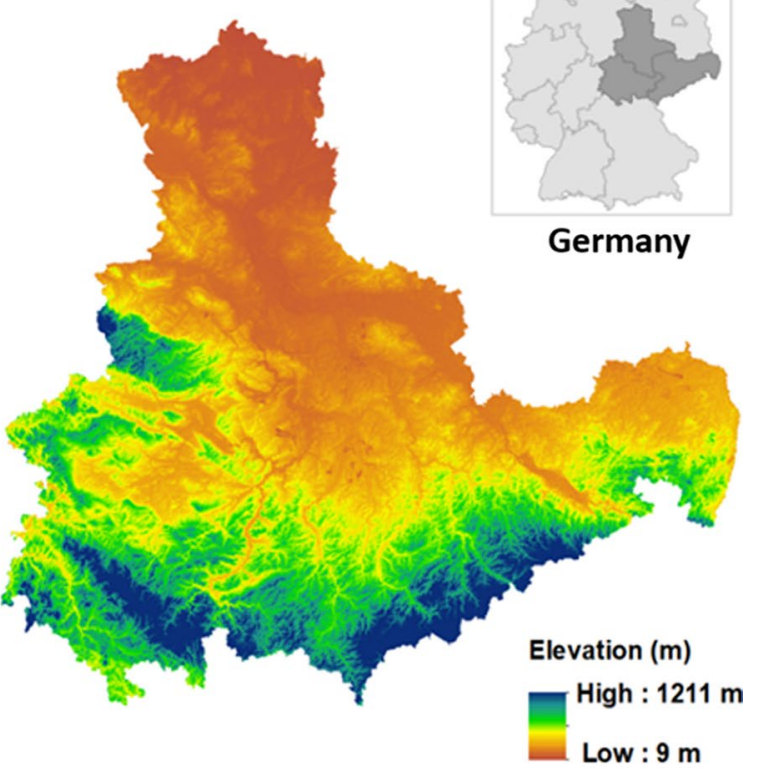

Fig. 3 Maps of Central Germany with a the distribution of biogas plants overlaid with administrative areas in Central Germany and $\mathbf{b}$ the digital elevation map. Source: EE-Monitor, Shuttle Radar Topography Mission (SRTM) and Germany administrative Area (NUTS3) 


$$
\begin{aligned}
Y_{1, t}= & \beta_{0,1}+\beta_{1,1} * X_{1}+\beta_{2,1} * Z_{1}+\beta_{t} * \mathrm{TD}_{t}+\varepsilon_{1, t}, \\
Y_{2, t+1}= & \beta_{0,2}+\beta_{1,2} * X_{2}+\beta_{2,2} * Z_{2}+\beta_{t+1} * \mathrm{TD}_{t+1}+\varepsilon_{2, t+1}, \\
Y_{n, t+m}= & \beta_{0, n}+\beta_{1, n} * X_{n}+\beta_{2, n} * Z_{n} \\
& +\beta_{t+m} * \mathrm{TD}_{t+m}+\varepsilon_{n, t+m} .
\end{aligned}
$$

In this example, variables $X$ and $Z$ on the right-hand side are the variables that explain the response variable $Y$. In terms of the time dummy variable, TD is assigned to each certain $n$th of the dependent variable $Y$. For example, the first dependent variable for an event on date $t$ is written as $Y_{1, t}$, and the corresponding time dummy variable $\mathrm{TD}_{t}$ in the regression equation system only takes on the value of 1 if the date is $t$. Otherwise it is 0 for all other dates during the entire period under investigation, i.e., $t+1, t+2, \ldots, t+m$. For each equation in the regression system, the regress and $Y$ is regressed to the corresponding regressors $X, Z$ and the time dummy variable TD. If the coefficient of TD is significant, there is an event effect in the sample dataset and the coefficient of dummy variable TD represents the effect of the event [59].
As dependent variables in the regression model, county-level data regarding the annual number of newly established biogas plants $\left(\mathrm{BP}_{x . t}\right)$ and the installed capacity of each newly established biogas plant $\left(\mathrm{IC}_{x . t}^{i}\right)$ were directly collected from the database.

In terms of the explanatory variables, the first variable was feedstock availability for biogas production $\left(\mathrm{BPI}_{x, t}\right)$, which was proxied in this study by the technical biogas potential. This indicator measures the total quantity of different types of feedstock, e.g., sewage sludge, animal residues, energy crops, etc., that is available for biogas production in a region [70-73]. As discussed in a previous study, substrate transportation of energy crops and livestock excrement is inefficient from both an economic and an environmental perspective [74]. Therefore, the biomass for biogas production is generally obtained from the immediate vicinity of the plant. This finding was confirmed by the research of Csikos et al. [75], who found that biogas plants are concentrated in areas where energy crops are widely cultivated. In addition, a relationship between technical biogas potential and biogas plant size was also identified [71]. This variable was calculated as follows:

$$
\mathrm{BPI}_{x, t}=\left(\left(\text { Cattle }_{x, t} * \mathrm{EGR}_{C}+\operatorname{Pig}_{x, t} * \mathrm{EGR}_{P}\right) * \operatorname{SubPro}_{L, t}+\left(\text { Maize }_{x, t} * \mathrm{EGR}_{M}+\mathrm{Grassland}_{x, t} * \mathrm{EGR}_{G}\right) * \operatorname{SubPro}_{E C, t}\right) / \operatorname{AdArea}_{x, t} .
$$

\section{Preparing data for empirical analysis}

In previous international studies, several factors were identified as having effects on the adoption of biogas production and choice of plant size. For our research on CG, we selected the factors of feedstock availability, awareness for the environment, income and local political governance from the literature. Our models also included the explanatory variables land price and the price for agriculture production received by the farmer as they might have an impact on adopting biogas production within the German context.

Unlike most of the previous research, which uses farm-level survey data [34, 36, 60,61], our study used county-level data to quantify the impact of environmental, social and economic factors on the adoption of biogas production and choice of plant size. Different annual CG county-level panel data were collected from various sources for the period from 2000 to 2014 . While the data could be directly obtained for some of the variables, for other variables, we needed to process the collected data first. Table 1 presents a general summary of the collected data. Missing data were estimated using the linear interpolation technique. If the data were not available at the county-level, national-level data were used.
Denoted as $\mathrm{BPI}_{x, t}\left(\mathrm{~mW} / \mathrm{km}^{2}\right)$, this variable first used the number of cattle $\left(\mathrm{Cattle}_{x, t}\right)$ and pigs $\left(\mathrm{Pig}_{x, t}\right)$ and the cultivated areas of silage maize (Maize ${ }_{x, t}$ ) and grassland $\left(\right.$ Grassland $\left._{x, t}\right)$ in county $x$ in year $t$ together with the electricity generation rates of those feedstock types $\left(\mathrm{EGR}_{C}, \mathrm{EGR}_{P}, \mathrm{EGR}_{M}\right.$ and $\left.\mathrm{EGR}_{G}\right)$ to calculate county $x$ 's theoretical ability to generate electricity from biogas plants for year $t$. Then the annual ability to generate electricity at a county level was adjusted according to the percentages of the substrates and divided by the area of the county in order to obtain the biogas potential per square kilometer.

The second independent variable was the awareness for the environment $\left(\mathrm{AE}_{x, t}\right)$. As reported in many previous studies, awareness for the environment influences the willingness to adopt renewable energy technologies [76]. In the current study, we used the Bündis 90/Die Grünen approval rating in the Landtag parliamentary election in each studied county to proxy the county-level awareness for the environment since Green party supporters are noted for being environmentally conscious [77]. Therefore, a county with a higher approval rating for the Green party should indicate that this county has a higher acceptance of biogas production. This variable was constructed as follows: 


$$
\mathrm{AE}_{x, t}=\frac{\mathrm{VG}_{x, t}}{\mathrm{TV}_{x, t}}
$$

The county-level awareness for the environment, denoted as $\mathrm{AE}_{x, t}$, was calculated by dividing the total number of valid votes for Bündnis 90/Die Grünen in the Landtag parliament election $\left(\mathrm{VG}_{x, t}\right)$ by the total number of valid votes in the Landtag parliament election from county $x$, in year $t\left(\mathrm{TV}_{x, t}\right)$.

The third variable was income $\left(\mathrm{DI}_{x, t}\right)$, which we have proxied by using annual disposable per capita income at the county level. As found in previous studies, a large number of biogas plants are privately operated in Germany [30]. Farmers who adopt biogas plants anticipate this and regard it as an investment that diversifies and increases their income [74, 78]. Even though the disposable per capita income in Germany is high, local farmers still need credit to finance their investment in biogas production [79]. Apart from the cost of construction and installation, investment in biogas production requires a series of other long-term costs, such as feedstock and annual operating costs [80]. As reported, the investment behavior of European households is largely influenced by changes in their disposable income and European households are cautious when taking out loans [81]. Therefore, we incorporated this variable in the model to study whether in a developed country such as Germany, disposable income still influences the adoption of biogas plants.

The fourth variable was local political governance, which was denoted as $\mathrm{GN}_{x, t}$. In Germany, the Bündnis 90/Die Grünen and the SPD parliamentary factions took the initiative, drafted the bill and secured allies in favor of the EEG $[82,83]$. Therefore, we used the proportion of seats in the Kreistag parliament held by the SPD and Bündnis 90/Die Grünen in each county as the proxy for local political governance.

The fifth variable was land price $\left(\mathrm{LP}_{x, t}\right)$. Arable land is one of the most important but scare production resources needed for both building plants and supplying feedstock. Farmers will only invest in a biogas plant if the production factors, e.g., farmland, are available or at least affordable [84]. The land market in Eastern Germany is similar to other European land markets and characterized by a high percentage of rental contracts [85]. Investors in biogas production often lease or buy agricultural land for their production activities [86]. Therefore, many previous studies reported that the competition for land between biogas plants and traditional forms of agriculture lead to a substantial increase in land prices [84, 86-88]. However, increasing land prices would eat up profits from biogas production investments since the guaranteed subsidy is fixed.
Therefore, the transaction-based land price should affect biogas production decision-making.

The last variable was the agriculture production price received by farmers $\left(\mathrm{PPAP}_{t}\right)$, which was proxied by Germany's annual Producer Price Index of Agricultural Products. As reported in other studies, operating a biogas plant is an alternative investment for farmers that allows them to diversify their income sources [74, 78]. In periods of high prices for agricultural products, farmers are reluctant to start biogas production and focus more on their agriculture business. In contrast, in periods of low prices for agricultural products, it is expected that farmers adopt biogas production to earn the guaranteed subsidies. Besides, in the dairy farming industry, when milk prices are unprofitable, the biomass grown on this pastureland would not be used for dairy feeding. If there is no alternative use for the biomass, e.g., for biogas production, the land would fall out of agronomic production. Therefore, to justify future cultivation of the grassland, biomass utilization must be diverted to energy production and concomitantly generate an income for the farmer [30].

The data regarding income, local political governance, land price and agriculture production price received by farmers were directly collected from the database listed in Table 1. The descriptive statistics of all selected variables are summarized in Table 2

\section{Model specification}

The EEGs could only remunerate farmers after the farmers had been informed about the EEG and had responded to the opportunity [16]. Therefore, there is a lag in the effects of the EEGs and environmental, social and economic factors on the biogas plants. Considering that the construction period of a biogas plant varies strongly from two months to two years depending on the size of the plant, we estimated the average building period of a biogas plant to be one year based on the data from BiogasWorld [89]. This one-year construction period was taken as the length of the lag effect. For example, a biogas plant that is not fully operational until year $t$ is the result of a building decision made by the owner based on the environmental, social and economic conditions and the EEG in year $t-1$.

We selected the period 2000 to 2014 for our study. This period was further divided into four sub-periods based on the timeline of the EEGs. The first period was from 2000 to 2003, corresponding to EEG,$E^{E E G}$ II covered the years between 2004 and 2008. The last two periods were EEG $\mathrm{EII}_{\text {and }}$ EEG IV spanning 2009 to 2011 and 2012 to 2014, respectively. Except for $\mathrm{EEG}_{\mathrm{I}}$, all the other three sub-periods were adopted in the EEG dummy variable categories to avoid the dummy variable trap [90]. As all 
other environmental, social and economic factors, the EEGs have a lag effect on biogas production investment. The EEG dummy variables $\mathrm{EEG}_{\mathrm{k}}$, with $\mathrm{k}=\mathrm{II}$, III and IV, are defined in this study as follows:

$$
\begin{aligned}
\mathrm{EEG}_{\mathrm{II}} & =\left\{\begin{array}{l}
1, t-1=2004,2005,2006,2007 \text { and } 2008 \\
0, \text { otherwise }
\end{array}\right. \\
\mathrm{EEG}_{\mathrm{III}} & =\left\{\begin{array}{l}
1, t-1=2009,2010 \text { and } 2011 \\
0, \text { otherwise, }
\end{array}\right. \\
\mathrm{EEG}_{\mathrm{IV}} & =\left\{\begin{array}{l}
1, t-1=2012 \text { and } 2013 \\
0, \text { otherwise. }
\end{array}\right.
\end{aligned}
$$

If all of the EEG dummy variables $E \mathrm{GG}_{k}$ take the value 0 , the period indicated is $E_{\mathrm{E}}$.

In the current study, we specified two model sets: Model I and Model II. In order to control for the biogas plant location effect, we further included the City variable in both model sets. If the biogas plant was constructed in an urban area, the City variable took the value of 1 , otherwise 0 . Model I had two sub-models (Model I.1 and Model I.2) and was a multivariate linear regression model to quantitatively study the effects on biogas production decisions. Model I.1 was used to explore the impact of environmental, social and economic factors on the decision to adopt biogas production. Model I.1 was constructed as follows:

Model I.1:

$$
\begin{aligned}
\mathrm{BP}_{x, t}= & \alpha+\ln \left(\mathrm{BPI}_{x, t-1}\right)+\ln \left(\mathrm{AE}_{x, t-1}\right) \\
& +\ln \left(\mathrm{DI}_{x, t-1}\right)+\ln \left(\mathrm{GN}_{x, t-1}\right)+\ln \left(\mathrm{LP}_{t-1}\right) \\
& +\ln \left(\mathrm{PPAP}_{t-1}\right)+\text { City }+\varepsilon
\end{aligned}
$$

Model I.2 was used to study the influences of environmental, social and economic factors on the choice of biogas plant size and was defined as follows:

\section{Model I.2:}

$$
\begin{aligned}
\ln \left(\mathrm{IC}_{x, t}^{i}\right)= & \alpha+\ln \left(\mathrm{BPI}_{x, t-1}\right)+\ln \left(\mathrm{AE}_{x, t-1}\right) \\
& +\ln \left(\mathrm{DI}_{x, t-1}\right)+\ln \left(\mathrm{GN}_{x, t-1}\right)+\ln \left(\mathrm{LP}_{t-1}\right) \\
& +\ln \left(\mathrm{PPAP}_{t-1}\right)+\mathrm{City}+\varepsilon
\end{aligned}
$$

Applying the event study econometric technique, we designed the model set Model II with sub-models Model II.1 and Model II.2 to quantify the impacts of EEG I to IV on the adoption of biogas production and choice of plant size after accounting for the environmental, social and economic effects. Compared to Model I.1 and Model I.2, Model II.1 and Model II.2 included the EEG dummy variable $\mathrm{EEG}_{k}$ to measure the EEG impacts. Model II.1, whose purpose was to study the EEG effects on adopting biogas production, was constructed as follows:

Model II.1:

$$
\begin{aligned}
\mathrm{BP}_{x, t}= & \alpha+\ln \left(\mathrm{BPI}_{x, t-1}\right)+\ln \left(\mathrm{AE}_{x, t-1}\right) \\
& +\ln \left(\mathrm{DI}_{x, t-1}\right)+\ln \left(\mathrm{GN}_{x, t-1}\right)+\ln \left(\mathrm{LP}_{t-1}\right) \\
& +\ln \left(\mathrm{PPAP}_{t-1}\right)+\text { City }+\mathrm{EEG}_{\mathrm{k}}+\varepsilon,
\end{aligned}
$$

$$
\begin{aligned}
& \text { withx }=1,2, \ldots, 50 ; t=2001,2002 \ldots, 2014 ; \text { and } \\
& \qquad k=\left\{\begin{array}{l}
I I, t-1=2004,2005,2006,2007 \text { and } 2008 \\
I I I, t-1=2009,2010 \text { and } 2011 \\
I V, t-1=2012 \text { and } 2013 .
\end{array}\right.
\end{aligned}
$$

Model II.2 aims to quantitatively analyze the impacts of different EEG amendments on the choice of plant size and was designed as follows:

Model II.2:

$$
\begin{aligned}
\ln \left(\mathrm{IC}_{x, t}^{i}\right)= & \alpha+\ln \left(\mathrm{BPI}_{x, t-1}\right)+\ln \left(\mathrm{AE}_{x, t-1}\right) \\
& +\ln \left(\mathrm{DI}_{x, t-1}\right)+\ln \left(\mathrm{GN}_{x, t-1}\right)+\ln \left(\mathrm{LP}_{t-1}\right) \\
& +\ln \left(\mathrm{PPAP}_{t-1}\right)+\mathrm{City}+\mathrm{EEG}+\varepsilon,
\end{aligned}
$$

$$
\begin{aligned}
& \text { withx }=1,2, \ldots, 50 ; t=2001,2002, \ldots, 2014 ; \text { and } \\
& \qquad k=\left\{\begin{array}{l}
I I, t-1=2004,2005,2006,2007 \text { and } 2008 \\
I I I, t-1=2009,2010 \text { and } 2011 \\
I V, t-1=2012 \text { and } 2013 .
\end{array}\right.
\end{aligned}
$$

\section{Methods and data for spatial analysis Methods and data for the impact analysis of environmental, social and economic factors on biogas production}

To spatially study the impacts of environmental, social and economic factors on biogas plant production density, we adopted the impact zone analysis approach of Csikos et al. [75]. Using the spatial join function of the ArcGIS 10.7 software, the data used in the empirical analysis of each investigated environmental, social and economic factor, except for PPAP, were assigned to the corresponding county to create the factor map. Then we utilized the Kernel Density tool within the ArcGIS 10.7 software to delineate three impact zones (A, B and C), which represent different biogas production density categories (low, medium and high). The separation of the biogas production density zones (impact zones A, B and C) followed the Jenks natural breaks classification procedure. In the end, we overlaid the impact zones layer with each factor map in CG to spatially illustrate the connection between the studied factor and the biogas production density. 


\section{Methods and data for impact analysis of EEG intended for agricultural land use}

In addition to the four previously defined EEG sub-periods, the Non-EEG period was introduced, covering the years from 1995 to 2000, in order to detect the influences of various EEG amendments on agricultural land use. We first overlapped the three impact zones on the countylevel map of CG to assign each county to a certain zone. Once the county impact zone assignment was completed, the annual data on various county-level agricultural areas were spatially linked to each corresponding county. After finishing the data preparation, we began a two-level evaluation: 1) at the utilized agricultural land (UTA) level, we calculated the ratios of arable land and grassland to UTA; 2 ) at the arable land level, we calculated the percentages of wheat, rye, triticale, silage maize, sugar beet and rapeseed of the total arable land. This spatial assessment was able to provide a general impression of the agricultural land use change from 1995 to 2014. In addition, a detailed analysis was made of the cultivation area of silage maize, the dominant energy crop, to the total arable land in each impact zone. A brief description of the data used in the spatial analysis is presented in Table 3 .

\section{Results}

In this section, the primary results of both the empirical and spatial analyses are presented in two sub-sections. The analysis of variance between the sub-models of Model I and II is summarized in Appendix Table 7. The multi-collinearity of all independent variables was verified using a variance inflation factor and the result can be found in Appendix Table 8. The regression residuals of all the sub-models were examined using regression diagnostic plots and reported in Appendix Figs. 9, 10, 11 and 12.

\section{Influences of environmental, social and economic factors on biogas production decisions}

\section{Results of the empirical analysis}

The regression results of Model I.1 and I.2 are summarized in Table 4. The regression result of Model I.1 showed that all of the environmental, social and economic variables we studied were significant to at least a 95\% confidence level. The coefficients of all the variables had their expected sign. The number of county-level biogas plants BP positively correlated with the availability of feedstock BPI, awareness for the environment $\mathrm{AE}$, income DI and local governance GN on a county level in CG. Additionally, the correlations between the number of biogas plants and the land price LP at the county level as well as the agriculture production price PPAP received by farmers were found to be negative. Of all the factors, disposable per capita income and the price of agriculture production had comparably strong effects on the decision of whether to adopt a biogas plant in CG. The results achieved for Model I.2 indicated significantly negative impacts of the availability of feedstock, income, and price of agriculture production on the choice of biogas plant size. In contrast, the awareness for the environment and local political governance positively correlated with the choice of plant size. Furthermore, land price played no role in influencing the choice of the biogas plant size.

\section{Results of the spatial analysis}

Three biogas production impact zones were identified in the studied area with value ranges of $0-3.80 \mathrm{~kW} / \mathrm{km}^{2}$ for impact zone A, $3.80-10.00 \mathrm{~kW} / \mathrm{km}^{2}$ for impact zone $\mathrm{B}$, and $10.00-18.70 \mathrm{~kW} / \mathrm{km}^{2}$ for impact zone C. If a certain impact zone comprised more than $50 \%$ of a county's area, this county was assigned to that impact zone. If no impact zone represented more than $50 \%$ of a county's area, the county was considered to be an impact zone $B$ county. In CG, 12 counties fell under impact zone A, 32 under impact zone B, and 6 under impact zone C. A spatial illustration of the biogas production impact zones is presented in Fig. 4.

We further linked the biogas production impact zones with each factor map. The results are depicted in Fig. 5. As shown, there was no clear pattern between feedstock availability and biogas production density. Some high biogas production density areas (impact zone $C$ ) were in counties where the technical biogas potential was considerably low. This could be also observed in the income factor. High and medium biogas production density

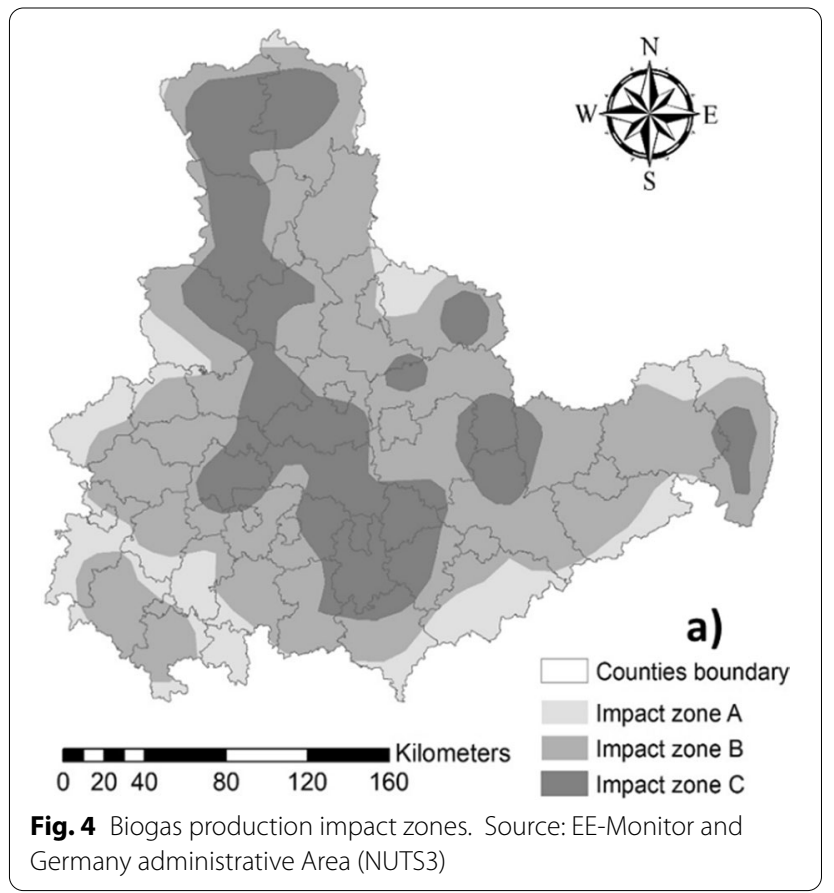




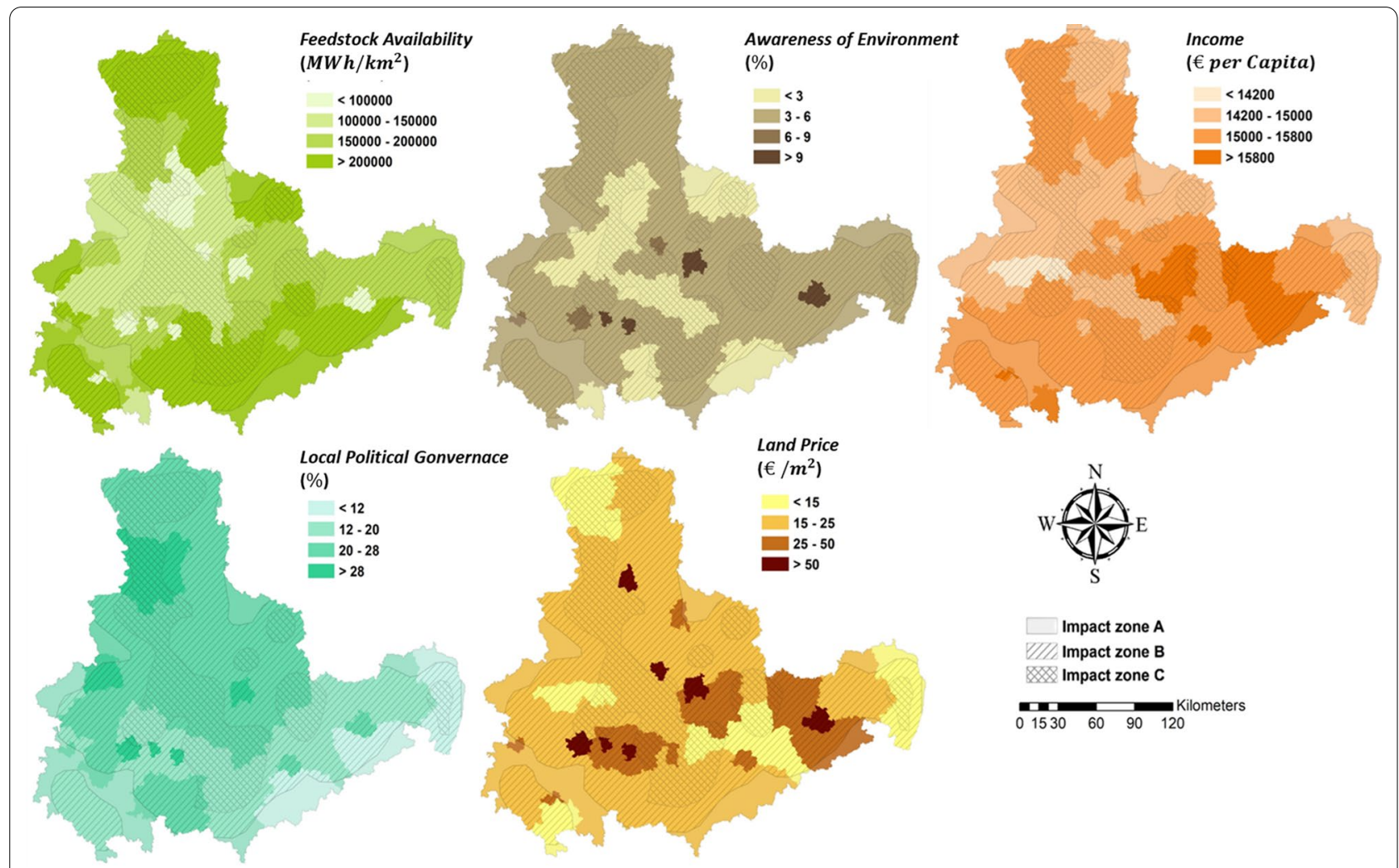

Fig. 5 Results of the spatial analysis on the influences of environmental, social and economic factors on biogas production decisions. Source: Regional Statistics Database of Germany

areas (impact zones $\mathrm{C}$ and $\mathrm{B}$ ) heavily overlapped with both high-income and low-income counties. In contrast, high and medium biogas production density areas more strongly overlapped with regions with a high awareness for the environment and local political governance, which had both positive effects on the adoption of biogas production and choice of plant size. In the empirical analysis, we found that land price had a negative influence on the construction of biogas plants, but no impact on the choice of plant size. The spatial analysis illustrated that areas with a high biogas production density were generally located in counties with medium to low land prices.

\section{Influences of the EEG on biogas production decisions and agricultural land use Results of the empirical analysis}

The regression results of Model II.1 and II.2 are summarized in Table 5. As shown in Model II.1, the number of newly established biogas plants increased significantly from the EEG I to III periods and slowed down in the EEG IV amendment period. EEG III had the strongest impact among the four EEG amendments we studied. During the EEG III period, each county had an average of 1.99 more biogas plant units in operation compared to the EEG I period, after controlling for all other effects. Unlike the results of Model II.1, only the EEG dummy variable EEG $E_{I I}$ in Model II.2 was significant, at a $99 \%$ confidence level, indicating that the average size of the biogas plants built during the EEG II period was $24 \%$ bigger than those built during the EEG I period, after accounting for all other effects. Apart from this, there was no significant difference in size between the biogas plants constructed under EEG I and under EEG III and IV after controlling for all other effects.

\section{Results of the spatial analysis}

Arable land and grassland area changes From the Non-EEG to the EEG IV period, the area of UTA in CG decreased continuously from $28,954.08$ to $28,661.08 \mathrm{~km}^{2}$. In the same period, the total area of arable land in CG also went down from $23,563.05$ to $23,256.86 \mathrm{~km}^{2}$. In contrast to UTA and arable land, the total area of grassland in CG fluctuated between $5,266.80$ and $5,336.91 \mathrm{~km}^{2}$ with an increase of less than $0.1 \%$ from the Non-EEG to the EEG IV period. Changes in the proportion of arable land and grassland under UTA in each impact zone are displayed in Fig. 6. While increasing trends for proportions 


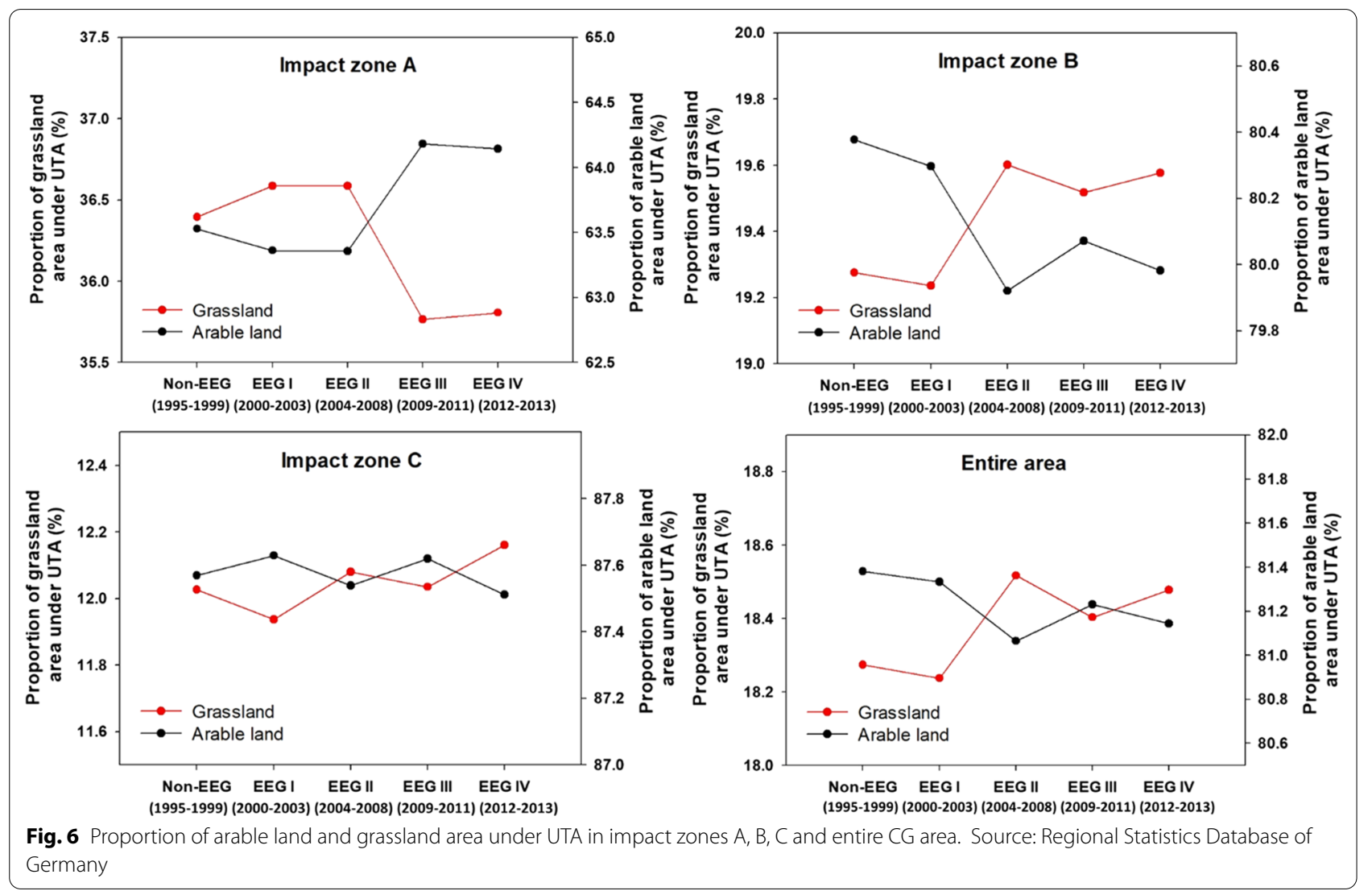

of grassland in UTA could be observed in medium and high-density biogas production zones, the proportion of grassland in impact zone A decreased. In terms of the proportion of arable land under UTA, the opposite trends to grassland were observed in all three zones. In general, the proportions of grassland and arable land under UTA in CG showed increasing and decreasing trends from the Non-EEG to the EEG IV periods, respectively.

Maize expansion influenced by biogas plant development The change analysis for the cultivation areas of major crops showed that the planting areas of the energy crops silage maize and rapeseed increased by $57.85 \%$ and $76.49 \%$, respectively, from the Non-EEG to the EEG IV period. Wheat was cultivated on around $45.79 \%$ of the area of major agriculture crops and accounted for the largest proportion of any crop throughout the period under investigation. Compared to the Non-EEG period, the cultivated area of wheat in EEG IV increased by $37.53 \%$, while rye, triticale and sugar beet all declined over the same period. Of these crops, the area for triticale cultivation decreased significantly by $25.74 \%$ (see Fig. 7a).

In CG, the proportion of the area for silage maize cultivation in arable land increased from the Non-EEG to the EEG IV period (see Fig. 7b). Compared to the proportion of silage maize in the Non-EEG period, the proportions in EEGs I to IV were 8.84\%, 20.16\%, 45.12\% and 59.93\% higher, respectively. However, the patterns differ when it comes to specific impact zones. In the Non-EEG period, the highest proportion of silage maize was identified in impact zone $\mathrm{A}$, while the proportion of maize cultivation in impact zone $C$ was the lowest. Since then, there have been strong increases in the proportion of silage maize in impact zones B and C, while impact zone A only showed a mild increase. Starting in EEG III, the proportion of silage maize in impact zone $\mathrm{C}$ was the highest among all the zones.

\section{Discussion}

Influences of environmental, social and economic factors on biogas plant adoption and size

The regression results of Model I.1 and Model I.2 showed that almost all of the environmental, social and economic variables studied correlated significantly with both the adoption and size of biogas plants in CG. The spatial analysis presented in Fig. 5 also supported the empirical results.

The awareness for the environment and the local political governance had the same expected signs in both Model I.1 and I.2, after controlling for all other effects. 

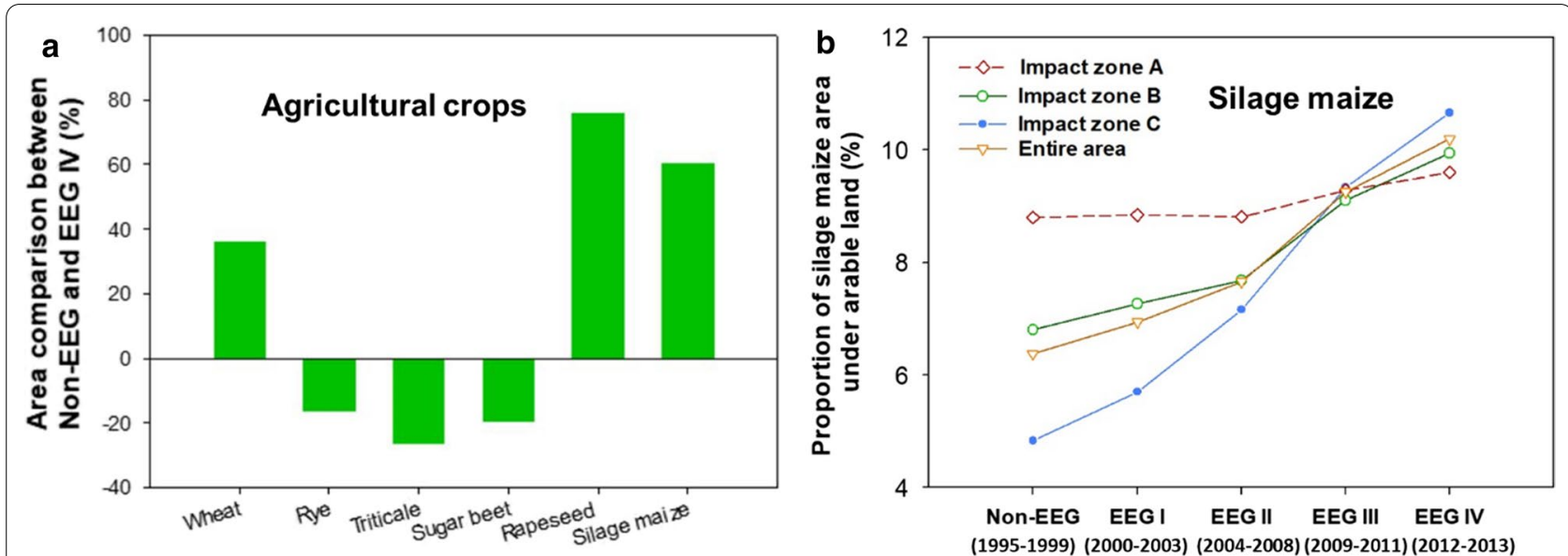

Fig. 7 Status of $\mathbf{a}$ changes in the area of agricultural crops and $\mathbf{b}$ the percentage of silage maize cultivation on arable land in each impact zone. Source: Regional Statistics Database of Germany

The positive correlations between these two variables and adoption and size of biogas plants were in line with most of the previous studies [33-38]. The spatial analysis also indicated that, except for the cities, the high and medium biogas production impact zones (impact zones $\mathrm{C}$ and $\mathrm{B}$ ) largely overlapped with regions that had a relatively high environmental awareness and local political governance ratio. In addition, the price of agricultural products was, as expected, negatively correlated with the biogas production decision. This finding could be explained by the argumentation that biogas production constituted an alternative investment for the farmers in order to diversify their sources of income [74, 78].

Feedstock availability had a positive sign in Model I.1 and was in line with many previous studies. This indicated that biogas plants were more likely to be built in regions where substrate resources were plentiful [70-73]. The negative sign of this variable in Model I.2 was mainly because a large number of biogas plants in CG were private farm-scale plants [92]. In regions with a high technical biogas potential, biomass could be supplied in the direct vicinity of a farm-scale biogas plant [74]. However, in counties with a low technical biogas potential, a larger biogas plant might be built and supported by several farms as it is not economical to build a biogas plant for each farm, even after considering the cost of feedstock transportation [92]. Since the total regional biogas production volume was the product of the number of biogas plants and average installed plant capacity, regions rich in feedstock might not have high biogas production outputs. This finding was also reflected in the spatial analysis in that a large proportion of high and medium impact zones were in regions where the biomass for biogas production was less plentiful.
As with feedstock availability, the disposable per capita income positively correlated with the decision to operate a biogas plant, but negatively influenced the choice of size. Therefore, as we also observed in the spatial analysis, the figure showed no significant pattern in the relation between biogas production density and income. In Germany, the adoption of biogas production involved a series of investments in time and capital [88, 93]. In particular, the construction and installation of private biogas plants were largely achieved with the help of a loan provided by different credit institutions [79]. Therefore, farmers with high disposable income could be granted loans more easily compared to others and were more likely to operate biogas plants. However, if the income of the farmers was higher than a certain level, they might be reluctant to build a large-scale biogas plant since it required more time to operate. Many scholars argue that the adoption of biogas production has been an alternative investment for many farmers as a way to diversify their income. The income diversification effect of biogas production was not significant for farmers who could earn much more from other sources.

In line with many previous studies, the land price in this study had the expected negative correlation on the decision to build a biogas plant but no effect on the choice of plant size. This empirical finding was also reflected in the spatial analysis, which showed that, in particular, impact zone $C$ lay generally in the counties with medium or low land prices. In Germany, investors in biogas production often leased or bought agricultural land for their production [86]. The high rental and purchase price for land would squeeze out the profit from biogas production investments and thus reduce their willingness to start biogas production. However, there was no effect 
detectable of the price on the choice of biogas plant size. Instead it was strongly influenced by other factors such as output prices in accordance with legislation, the availability of raw materials, and ensuing transportation and production costs [23, 94].

In general, the strong influence of the price of agriculture products and per capita disposable income pointed to the fact that the income diversification effect of biogas production plays a vital role in biogas production decision-making. In the biogas production decision-making process, farmers pay more attention to whether the biogas production is profitable after taking the cost of production, such as land price, into account, and whether the profits from biogas production can strongly contribute to income diversification.

\section{Influence of different EEG amendments on adoption and size of biogas plants}

All of the EEGs have the ultimate goal of increasing the contribution of renewable energy to total electricity consumption in Germany [16-20]; however, the impact of each EEG amendment on promoting the adoption of biogas production varied. As reported in other studies, the growth of the biogas sector was much faster in the EEGs I to III periods and slowed down during the amendment of the EEG in 2012 [32, 95]. This could also be observed in Appendix Fig. 13. After a rapid increase in the cumulative number of biogas plants from EEG I to III in CG, expansion slowed down during the EEG IV period.

The findings achieved for Model II.1 confirmed the distinctive results achieved for different EEG amendments from 2000 to 2014. Compared to EEG I, the EEG II and III periods saw an average of 1.40 and 1.99 more units of newly built biogas plants in each county in CG after controlling for all other effects. Expansion during the EEG II period was mainly due to the newly introduced biomass bonus, which, from 2005 and 2006, substantially encouraged biogas production using energy crops [23]. However, since 2007, agricultural biomass prices have raised considerably, which reduced the number of new power plants built in 2007 and 2008. The stronger increase in the number of biogas plants observed with the EEG 2009 amendment was the consequence of an enlarged subsidy scheme, an increase in basic subsidies and the biomass bonus [72].

The expansion of biogas plants during the EEG IV period slowed down compared to preceding years. There was an average of 1.44 more units of newly constructed plants in each county in CG during the EEG IV period compared to the EEG I period, which were 0.55 fewer units compared to the EEG III period. The reasons behind this were an altered funding scheme and the introduction of a "maize cap" in the newly amended EEG 2014 [95]. As of 2004, EEG II started to encourage the use of energy crops such as silage maize for biogas production [96]. After the implementation of EEG III, the cultivation of silage maize for biogas production increased significantly. Therefore, the "maize cap" was introduced under EEG IV [19]. Starting in 2012, the biogas sector started to be integrated into the German electricity market with fewer subsidies and using new mechanisms such as the market and the flexibility premium. As a consequence, EEG IV lowered the growth rates of silage maize cultivation for biogas production and the biogas production industry in Germany $[97,98]$.

In terms of the impact of EEG I to IV on the size of the biogas plants in CG, the regression results achieved for Model II.2 matched the average size of newly constructed biogas plants under each EEG amendment in CG, as presented in Appendix Fig. 13. The average installed capacity of the newly constructed plants under EEG II was the highest among all the amendments studied. Under EEG III, the subsidy for small-scale use was raised to encourage the adoption of this type of plant. Therefore, it was argued that the plants constructed in the EEG III period should mainly be small-scale plants [23]. Due to the development in technology, a new subsidy category was introduced for $75 \mathrm{~kW} / \mathrm{h}$ manure-based biogas plants in the next EEG IV period that was the most profitable of all categories [24]. This was to reinforce the support for the development of small-scale biogas plants [99]. In summary, the adoption of small-scale plants was strongly promoted starting under EEG III. However, the empirical results were unable to detect any decrease in the average size of biogas plants constructed in the EEG III and IV periods. There was no significant difference in

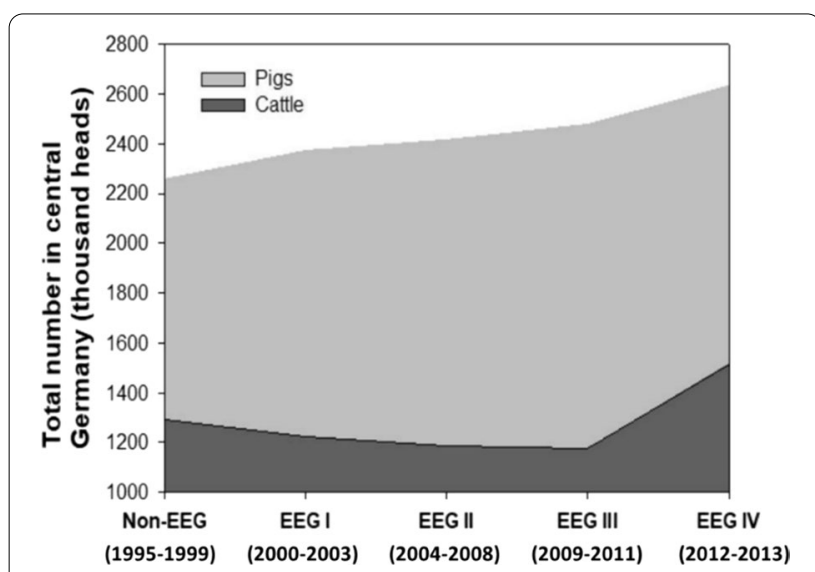

Fig. 8 Number of cattle and pigs on hand in Central Germany from the Non-EEG to EEG IV period. Source: Regional Statistics Database of Germany 
the average installed capacity of biogas plants between EEG I and EEG III and IV. The reason behind this could be that the choice of plant size was mainly influenced by the operator's own situation and needs, such as feedstock transportation costs, production costs and available working time [23, 24, 94]. Therefore, our county-level analysis was unable to capture these factors, which was reflected by the low value of Adjusted $R^{2}$ in Model II.2.

\section{Maize expansion status in CG}

A central topic in the discourse on agricultural biogas production was the question of whether the expansion of biogas production leads to land competition between permanent grassland and silage maize cultivation [100]. Our study indicated that the proportion of silage maize in the total area of arable land increased rapidly during the EEG period. Starting from EEG III, the proportion of silage maize was the highest in regions where biogas production density was also high. This is consistent with the findings obtained in studies conducted in SchleswigHolstein and Hesse $[75,101]$. We also observed that the effect of the "maize cap" introduced under EEG IV played a very limited role in decreasing the growth rate of maize cultivation in CG. However, Vergara and Lakes [98] found a significant slowdown in the silage maize growth rate in the nearby region of Brandenburg during the EEG IV period. One possible reason was the difference in the data used in their analysis. In our study, the data on the silage maize cultivation area were only the aggregated total of the cultivation areas. Vergara and Lakes [98] used the Integrated Administration and Control System (IACS), which classified the total silage maize cultivation area into different groups according to utilization purposes, e.g., biogas production, crop plants, fodder crops. Therefore, we were unable to conclude whether EEG IV was effective in controlling "maizification of the landscape" in CG.

In terms of the grassland in CG, the total area of permanent grassland slightly increased by $0.1 \%$ and the proportion of grassland in UTA remained stable at around $18.41 \%$ from the Non-EEG to the EEG IV period. However, other researchers described different observations in other German states. For instance, Lüker-Jans et al. [101] reported a decrease in the total area of permanent grassland in Hesse during the EEG period. In Lower Saxony and Schleswig-Holstein, reductions in grassland were also observed from 1999 to 2013 [102, 103]. According to the EE-Monitor dataset, Lower Saxony and SchleswigHolstein had the highest biogas production density in Germany, with values of 22.99 and $23.11 \mathrm{~kW} / \mathrm{km}^{2}$, respectively $[62,63]$. In contrast, the biogas production density of CG was $8.94 \mathrm{~kW} / \mathrm{km}^{2}$. The rapid expansion of biogas plants in Lower Saxony and Schleswig-Holstein might have had a negative influence on the local grassland conservation. The small increase in grassland area in CG observed during the EEG period might be due to the fact that farmers adopted a combination of biogas and livestock production to better diversify their farming investments [88]. This view could be supported by the fact that the numbers of livestock, especially catthe and pigs, gradually rose in CG (see Fig. 8). Furthermore, between 2008 and 2013, the milk quota system was phased out by raising the quota $1 \%$ each year. This made dairy farming more and more attractive to farmers [104]. As shown in Appendix Fig. 14, the livestock business in Germany also became more profitable since the prices of dairy products and meat have shown upwards trends in the last two decades. Furthermore, the EU's Common Agricultural Policy (CAP) reform in 2013 regulated "greening" obligations to incentivize farmers to conduct environmentally sound farming practices such as crop diversification and maintaining ecologically rich landscape features [105]. To meet the greening requirement, the percentage of grassland relative to arable land in each district of Germany should not decrease by more than $5 \%$ over the 2012 levels. These regulatory forces left scope for an increase in grassland in CG [106].

\section{Outlook and implications for future studies}

In contrast to previous research that used farm-level data to study the factors that influence the adoption of biogas production in a certain area, this study's approach can be applied to other regions in Germany by updating the input data. The results of this study were able to provide information on the influence of environmental, social and economic factors on biogas plant development, as well as their spatial association through various biogas production density impact zones. This could serve as a starting point for a more detailed farm-level study in the future and can also be validated by a survey-based dataset. Based on the findings of our research that disposable per capita income and agricultural product prices strongly correlated with the biogas production decision, future studies should pay more attention to the income diversification effect of biogas production on the adoption decision. Additionally, our study emphasized the importance of spatial analysis. Due to the regional heterogeneity caused by spatial characteristics, e.g., topographic, soil, climatic, and other social-economic variations, the EEG's impact on different regions in Germany still contains large discrepancies. Therefore, to understand policy effectiveness at a national level, future studies should take into account environmental, social and economic factors, as well as regional spatial-temporal agricultural land use change. We should also note that the maize expansion detected in our study and the change in grassland 
Table 1 Description of the collected data for empirical analysis

\begin{tabular}{|c|c|c|c|c|}
\hline Data source & Variable & Abbreviation & Level & Unit \\
\hline \multirow[t]{2}{*}{$\begin{array}{l}\text { Helmholtz-Centre for Environmental Research (UFZ) } \\
\text { EE-Monitor }[62,63]\end{array}$} & $\begin{array}{l}\text { Number of newly established biogas plants in county } \\
x \text {, in year } t\end{array}$ & $\mathrm{BP}_{x . t}$ & County & - \\
\hline & $\begin{array}{l}\text { Installed capacity of } i \text { newly established biogas plants } \\
\text { in county } x \text {, in year } t\end{array}$ & $I C_{x . t}^{i}$ & Biogas Plant & $\mathrm{kW} / \mathrm{h}$ \\
\hline \multirow[t]{6}{*}{ Regional Statistics Database of Germany [53] } & Headcount of cattle in county $x$, in year $t$ & Cattle $e_{x, t}$ & County & Head \\
\hline & Headcount of pigs in county $x$, in year $t$ & $\operatorname{Pig}_{x, t}$ & County & Head \\
\hline & Area of cultivated silage maize in county $x$, in year $t$ & Maize $_{x, t}$ & County & ha \\
\hline & Area of grassland in county $x$, in year $t$ & Grassland $_{x, t}$ & County & $\mathrm{Ha}$ \\
\hline & Disposable per capita income in county $x$, in year $t$ & $\mathrm{Dl}_{x, t}$ & County & $€$ \\
\hline & $\begin{array}{l}\text { Average transaction-based land price in county } x \text {, in } \\
\text { year } t\end{array}$ & $L P_{x, t}$ & County & $€ / m^{2}$ \\
\hline \multirow{3}{*}{$\begin{array}{l}\text { Statistical Office of Saxony [64] } \\
\text { Statistical Office of Saxony-Anhalt [65] } \\
\text { Statistical Office of Thuringia [66] }\end{array}$} & $\begin{array}{l}\text { Proportion of seats in Kreistag parliament held by SPD } \\
\text { and Bündnis 90/Die Grünen in county } x \text {, in year } t\end{array}$ & $G N_{x, t}$ & County & - \\
\hline & $\begin{array}{l}\text { Total valid votes in Landtag parliamentary election in } \\
\text { county } x \text {, in year } t\end{array}$ & $\mathrm{TV}_{x, t}$ & County & - \\
\hline & $\begin{array}{l}\text { Total valid votes for Bündnis 90/Die Grünen in Landtag } \\
\text { parliamentary election in county } x \text {, in year } t\end{array}$ & $V G_{x, t}$ & County & - \\
\hline \multirow[t]{4}{*}{ Agency for Renewable Resources [67] } & $\begin{array}{l}\text { Annual cattle excrement electricity generation rate per } \\
\text { headcount }\end{array}$ & $E G R_{C}$ & - & kWh/head \\
\hline & $\begin{array}{l}\text { Annual pig excrement electricity generation rate per } \\
\text { headcount }\end{array}$ & $\mathrm{EGRp}$ & - & kWh/head \\
\hline & Annual maize electricity generation rate per hectare & $E G R_{M}$ & - & kWh/ha \\
\hline & Annual grassland electricity generation rate per hectare & $E G R_{G}$ & - & kWh/ha \\
\hline \multirow[t]{2}{*}{ German Biomass Research Center (DBFZ) [68] } & Proportion of biogas plants with livestock as substrate & SubPro $L, t$ & National & - \\
\hline & Proportion of biogas plants with feedstock as substrate & SubPro $_{E C, t}$ & National & - \\
\hline Federal Statistical Office of Germany [69] & $\begin{array}{l}\text { Index of producer prices of agricultural products in } \\
\text { year } t\end{array}$ & $\mathrm{PPAP}_{t}$ & National & - \\
\hline
\end{tabular}

Table 2 Descriptive statistics of all the variables used in the regression model

\begin{tabular}{llllllr}
\hline Variables & Min & Median & Mean & Max & SD & Sample size \\
\hline BP (number/county) & 0.00 & 1.00 & 1.45 & 16.00 & 2.21 & 700 \\
IC(kWh/biogas plant) & 15.00 & 494.50 & 477.53 & $5,309.00$ & 344.80 & 1016 \\
BPI(MWh/km $\left.{ }^{2}\right)$ & 60,733 & 197,765 & 207,168 & 383,263 & 72,566 & 700 \\
AE(\%) & 1.50 & 3.98 & 4.05 & 12.96 & 1.41 & 700 \\
DI( $€$ per capita) & 12,170 & 15,564 & 15,596 & 19,064 & 1282 & 700 \\
GN(\%) & 9.50 & 21.54 & 20.44 & 40.38 & 5.70 & 700 \\
LP(€/m $\left.{ }^{2}\right)$ & 1.74 & 19.14 & 21.03 & 156.82 & 13.33 & 700 \\
PPAP & 83.10 & 95.00 & 93.97 & 114.70 & 10.00 & 14 \\
\hline
\end{tabular}

during the EEG period might have also been the result of other policies implemented in the same period, such as the obligation to set aside land and the "greening" obligation of CAP, as well as the milk quota [15, 104, 105]. Therefore, a future study focusing on the impact of the EEG on the environment should find a suitable research method that could strip all of the effects of other policies. Finally, if models could provide or generate spatial-temporal data on energy crop distribution in the future study, it would be possible to conduct more detailed landscape analyses such as resource optimization and trade-off analysis between the environmental costs and economic gain of adopting biogas plants.

\section{Conclusion}

The current study integrated empirical analysis with spatial analysis to better understand the impact of environmental, social and economic factors and the EEG 
Table 3 Description of the collected data for spatial analysis

\begin{tabular}{|c|c|c|c|c|}
\hline Data source & Data & Type & Level & Unit \\
\hline \multirow[t]{5}{*}{ Own calculation } & $\left.B P\right|_{x, t}$ & Statistical & County & $\mathrm{MWh} / \mathrm{km}^{2}$ \\
\hline & $A E_{x, t}$ & Statistical & County & - \\
\hline & $D l_{x, t}$ & Statistical & County & $€$ \\
\hline & $\mathrm{GN}_{x, t}$ & Statistical & County & - \\
\hline & $L P_{t}$ & Statistical & County & $€ / m^{2}$ \\
\hline \multirow{2}{*}{$\begin{array}{l}\text { Helmholtz Centre for } \\
\text { Environmental Research } \\
\text { (UFZ) } \\
\text { EE-Monitor }[62,63]\end{array}$} & $\mathrm{BP}_{x, t}$ & Spatial & Biogas plant & - \\
\hline & $I C_{x, t}^{i}$ & Spatial & Biogas plant & $\mathrm{kW} / \mathrm{h}$ \\
\hline \multirow{4}{*}{$\begin{array}{l}\text { Regional Statistics Database } \\
\text { of Germany [53] }\end{array}$} & Area of utilized agricultural land in county $x$, in year $t$ & Statistical & County & ha \\
\hline & Area of arable land in county $x$, in year $t$ & Statistical & County & ha \\
\hline & Area of grassland in county $x$, in year $t$ & Statistical & County & ha \\
\hline & $\begin{array}{l}\text { Cultivation areas of wheat, rye, triticale, maize, sugar beet and } \\
\text { rapeseed in county } x \text {, in year } t\end{array}$ & Statistical & County & ha \\
\hline Eurostat [91] & Germany administrative area (NUTS3) & Spatial & County & - \\
\hline
\end{tabular}

Table 4 Results of the multivariate regression for both Model I.1 and Model 1.2

\begin{tabular}{|c|c|c|c|c|}
\hline \multirow[t]{2}{*}{ Variables } & \multicolumn{2}{|c|}{$\begin{array}{l}\text { Model I.1 (number of biogas } \\
\text { plants } B P \text { ) }\end{array}$} & \multicolumn{2}{|c|}{$\begin{array}{l}\text { Model } 1.2 \text { (installed } \\
\text { capacity IC) }\end{array}$} \\
\hline & Coefficient & Standard error & Coefficient & $\begin{array}{l}\text { Standard } \\
\text { error }\end{array}$ \\
\hline Intercept & $-30.09^{* *}$ & 11.08 & $21.03^{* * *}$ & 3.77 \\
\hline \multicolumn{5}{|c|}{ Environmental, social, economic variables } \\
\hline $\ln (\mathrm{BPI})$ & $0.34^{*}$ & 0.16 & $-0.25^{* * *}$ & 0.06 \\
\hline $\ln (A E)$ & $0.78^{* *}$ & 0.26 & $0.28^{* *}$ & 0.10 \\
\hline $\ln (\mathrm{Dl})$ & $5.53^{* * *}$ & 1.40 & $-1.01^{*}$ & 0.46 \\
\hline $\ln (G N)$ & $0.64^{*}$ & 0.27 & $0.26^{* * *}$ & 0.07 \\
\hline $\ln (L P)$ & $-0.81^{* * *}$ & 0.18 & 0.00 & 0.04 \\
\hline $\ln \left(\mathrm{PPAP}_{t}\right)$ & $-5.70^{* * *}$ & 0.99 & $-0.76^{* *}$ & 0.27 \\
\hline \multicolumn{5}{|c|}{ Control variables } \\
\hline City & $-1.36^{* * *}$ & 0.29 & $-0.51^{* *}$ & 0.18 \\
\hline Adjusted $R^{2}$ & \multicolumn{2}{|c|}{0.21} & \multicolumn{2}{|c|}{0.08} \\
\hline Sample size & \multicolumn{2}{|c|}{700} & \multicolumn{2}{|c|}{1016} \\
\hline
\end{tabular}

"“**", " "**", "**" and "." denote 99.9\%, 99\%, 95\% and 90\% confidence levels, respectively

amendments on biogas production decisions and the environment. The empirical result of the effects of environmental, social and economic factors on biogas production decisions indicated the importance of the income diversification effect of biogas production for the potential biogas plant operators in CG. By using the event study econometric technique, we found that the EEG was effective in promoting the adoption of biogas production in CG. However, in terms of the choice of plant size, despite there being a clear encouragement to adopt small-scale biogas plants in EEG III and IV, we did not observe a decrease in the average size of the plants constructed in
Table 5 Results of the multivariate regression for both Model II.1 and Model II.2

\begin{tabular}{|c|c|c|c|c|}
\hline \multirow[t]{2}{*}{ Variables } & \multicolumn{2}{|c|}{$\begin{array}{l}\text { Model II.1 (number of biogas } \\
\text { plants BP) }\end{array}$} & \multicolumn{2}{|c|}{$\begin{array}{l}\text { Model II.2 (installed } \\
\text { capacity IC) }\end{array}$} \\
\hline & Coefficient & Standard error & Coefficient & $\begin{array}{l}\text { Standard } \\
\text { error }\end{array}$ \\
\hline Intercept & 13.56 & 16.56 & $12.35^{*}$ & 4.96 \\
\hline \multicolumn{5}{|c|}{ Environmental-social-economic variables } \\
\hline $\ln (\mathrm{BPI})$ & $0.46^{* *}$ & 0.16 & $-0.21^{* * *}$ & 0.06 \\
\hline $\ln (A E)$ & 0.14 & 0.28 & $0.19^{\circ}$ & 0.11 \\
\hline $\ln (\mathrm{DI})$ & -0.20 & 1.92 & -0.30 & 0.57 \\
\hline $\ln (G N)$ & $0.56^{*}$ & 0.27 & $0.30^{* * *}$ & 0.07 \\
\hline $\ln (L P)$ & $-0.55^{* *}$ & 0.18 & 0.00 & 0.04 \\
\hline $\ln \left(\mathrm{PPAP}_{t}\right)$ & $-3.68^{* *}$ & 1.16 & -0.47 & 0.33 \\
\hline \multicolumn{5}{|c|}{ Control variables } \\
\hline City & $-0.93^{* *}$ & 0.29 & $-0.42^{*}$ & 0.19 \\
\hline \multicolumn{5}{|c|}{ EEG dummy variables } \\
\hline $\mathrm{EEG}_{\|}$ & $1.40^{* * *}$ & 0.26 & $0.24^{* *}$ & 0.09 \\
\hline$E E G_{\| I}$ & $1.99^{* * *}$ & 0.40 & 0.05 & 0.12 \\
\hline $\mathrm{EEG}_{\mid \mathrm{V}}$ & $1.44^{* *}$ & 0.49 & -0.12 & 0.15 \\
\hline Adjusted $R^{2}$ & \multicolumn{2}{|c|}{0.25} & \multicolumn{2}{|c|}{0.10} \\
\hline Sample size & \multicolumn{2}{|c|}{700} & \multicolumn{2}{|c|}{1016} \\
\hline
\end{tabular}

"****," "***", "**" and "." denote 99.9\%, 99\%, 95\% and 90\% confidence levels, respectively

these two periods. The analysis of agricultural land use change illustrated that the development of biogas production in CG was associated with maize expansion, especially in regions with a high installed capacity for biogas. We also observed that, during the period under investigation, the area of arable land declined while the grassland area increased in CG. Apart from the CAP greening obligations for grassland conservation, the farmers' adoption 
of a combination of livestock farming and biogas production as a way to have diversified sources of income in CG might be the reason behind this observation.

\section{Appendix}

See Tables 6, 7, 8 and Figs. 9, 10, 11, 12, 13,14.

Here, we choose the variance inflation factor threshold of 10 .
Table 7 Results of ANOVA for linear model fits test for both Model I and Model II

\begin{tabular}{|c|c|c|c|c|c|}
\hline Model & Residual DF & RSS & Sum of square & $F$ & $p$-Value \\
\hline \multicolumn{6}{|c|}{$\begin{array}{l}\text { Model I: } \mathrm{BP}=a+\ln (\mathrm{BPI})+\ln (\mathrm{AE})+\ln (\mathrm{DI})+\ln (\mathrm{GN})+\ln (\mathrm{LP})+\ln (\mathrm{PPAP})+ \\
\quad \text { City }+(\mathrm{EEG})+\varepsilon\end{array}$} \\
\hline 1.1 & 693 & 2792.90 & & & \\
\hline$\| .1$ & 690 & 2634.80 & 158.16 & 13.81 & $0.00^{* * *}$ \\
\hline \multicolumn{6}{|c|}{$\begin{array}{l}\text { Model II: } \ln (\mathrm{IC})=a+\ln (\mathrm{BPI})+\ln (\mathrm{AE})+\ln (\mathrm{DI})+\ln (\mathrm{GN})+\ln (\mathrm{LP})+\ln (\mathrm{PPAP} \\
\quad)+ \text { City }+\mathrm{EEG}+\varepsilon\end{array}$} \\
\hline 1.2 & 1008 & 447.34 & & & \\
\hline 11.2 & 1005 & 436.20 & 11.14 & 8.56 & $0.00^{* * *}$ \\
\hline
\end{tabular}

"****m***m**" and "." denote 99.9\%, 99\%, 95\% and 90\% confidence levels, respectively

Table 6 Remuneration policy for EEGs I to IV

\begin{tabular}{|c|c|c|c|c|c|c|c|c|c|}
\hline \multirow[t]{2}{*}{ Year } & \multirow[t]{2}{*}{ Installed capacity } & \multicolumn{8}{|c|}{ Remuneration in $€-c t / k W h$} \\
\hline & & Basic & $\mathrm{RR}^{1}$ & $M^{2}$ & Basic & $E R^{4}$ & $\mathrm{FCl}^{5}$ & Basic & $\mathrm{OW}^{7}$ \\
\hline \multicolumn{10}{|c|}{ Panel A: EEG I from March 29, 2000 to July 31, 2004} \\
\hline \multirow[t]{3}{*}{2000 to 2002} & Up to $500 \mathrm{kWel}$ & 10.10 & 2000 to 2002 & Up to $500 \mathrm{kWel}$ & 10.10 & 2000 to 2002 & Up to $500 \mathrm{kWel}$ & 10.10 & 2000 to 2002 \\
\hline & Up to $5 \mathrm{mWel}$ & 9.10 & & Up to $5 \mathrm{mWel}$ & 9.10 & & Up to $5 \mathrm{mWel}$ & 9.10 & \\
\hline & Above 5 mWel & 8.60 & & Above 5 mWel & 8.60 & & Above 5 mWel & 8.60 & \\
\hline \multirow[t]{3}{*}{2003} & Up to $500 \mathrm{kWel}$ & 10.00 & 2003 & Up to $500 \mathrm{kWel}$ & 10.00 & 2003 & Up to $500 \mathrm{kWel}$ & 10.00 & 2003 \\
\hline & Up to $5 \mathrm{mWel}$ & 9.00 & & Up to $5 \mathrm{mWel}$ & 9.00 & & Up to $5 \mathrm{mWel}$ & 9.00 & \\
\hline & Above 5 mWel & 8.50 & & Above 5 mWel & 8.50 & & Above 5 mWel & 8.50 & \\
\hline \multirow[t]{3}{*}{2004} & Up to $500 \mathrm{kWel}$ & 9.90 & 2004 & Up to $500 \mathrm{kWel}$ & 9.90 & 2004 & Up to $500 \mathrm{kWel}$ & 9.90 & 2004 \\
\hline & Up to $5 \mathrm{mWel}$ & 8.90 & & Up to $5 \mathrm{mWel}$ & 8.90 & & Up to $5 \mathrm{mWel}$ & 8.90 & \\
\hline & Above 5 mWel & 8.40 & & Above 5 mWel & 8.40 & & Above 5 mWel & 8.40 & \\
\hline \multicolumn{10}{|c|}{ Panel B: EEG II from August 1, 2004 to December 31, 2008 with annual basic remuneration degression: 1.5\% } \\
\hline \multirow[t]{4}{*}{2004 to 2008} & Up to $150 \mathrm{kWel}$ & 11.5 & 2004 to 2008 & Up to $150 \mathrm{kWel}$ & 11.5 & 2004 to 2008 & Up to $150 \mathrm{kWel}$ & 11.5 & 2004 to 2008 \\
\hline & Up to $500 \mathrm{kWel}$ & 9.90 & & Up to $500 \mathrm{kWel}$ & 9.90 & & Up to $500 \mathrm{kWel}$ & 9.90 & \\
\hline & Up to $5 \mathrm{mWel}$ & 8.90 & & Up to $5 \mathrm{mWel}$ & 8.90 & & Up to $5 \mathrm{mWel}$ & 8.90 & \\
\hline & Up to $20 \mathrm{mWel}$ & 8.40 & & Up to $20 \mathrm{mWel}$ & 8.40 & & Up to $20 \mathrm{mWel}$ & 8.40 & \\
\hline \multicolumn{10}{|c|}{ Panel C: EEG III from January 1, 2009 to December 31, 2011 with annual basic remuneration degression: 1.0\% } \\
\hline \multirow[t]{4}{*}{2009 to 2011} & Up to $150 \mathrm{kWel}$ & 11.55 & 2009 to 2011 & Up to $150 \mathrm{kWel}$ & 11.55 & 2009 to 2011 & Up to $150 \mathrm{kWel}$ & 11.55 & 2009 to 2011 \\
\hline & Up to $500 \mathrm{kWel}$ & 9.90 & & Up to $500 \mathrm{kWel}$ & 9.90 & & Up to $500 \mathrm{kWel}$ & 9.90 & \\
\hline & Up to $5 \mathrm{mWel}$ & 8.17 & & Up to $5 \mathrm{mWel}$ & 8.17 & & Up to $5 \mathrm{mWel}$ & 8.17 & \\
\hline & Up to $20 \mathrm{mWel}$ & 7.71 & & Up to $20 \mathrm{mWel}$ & 7.71 & & Up to $20 \mathrm{mWel}$ & 7.71 & \\
\hline \multicolumn{10}{|c|}{ Panel D: EEG IV from January 1, 2012 to July 31, 2014 with annual basic remuneration degression: 2.0\% } \\
\hline \multirow[t]{5}{*}{2012 to 2014} & Up to 75 kWel. $^{8}$ & 25.00 & 2012 to 2014 & Up to $75 \mathrm{kWel}^{8}{ }^{8}$ & 25.00 & 2012 to 2014 & Up to $75 \mathrm{kWel}^{8}$ & 25.00 & 2012 to 2014 \\
\hline & Up to $150 \mathrm{kWel}$ & 14.30 & & Up to $150 \mathrm{kWel}$ & 14.30 & & Up to $150 \mathrm{kWel}$ & 14.30 & \\
\hline & Up to $500 \mathrm{kWel}$ & 12.30 & & Up to $500 \mathrm{kWel}$ & 12.30 & & Up to $500 \mathrm{kWel}$ & 12.30 & \\
\hline & Up to $5 \mathrm{mWel}$ & 11.00 & & Up to $5 \mathrm{mWel}$ & 11.00 & & Up to $5 \mathrm{mWel}$ & 11.00 & \\
\hline & Up to $20 \mathrm{mWel}$ & 6.00 & & Up to $20 \mathrm{mWel}$ & 6.00 & & Up to $20 \mathrm{mWel}$ & 6.00 & \\
\hline
\end{tabular}

Source: EEG-Vergütungssätze (2000-2004); Mindestvergütungssätze nach dem neuen Erneuerbare-Energien-Gesetz (EEG). vom 21. Juli 2004; Vergütungssätze und Degressionsbeispiele nach dem neuen Erneuerbare-Energien-Gesetz (EEG). vom 31. Oktober 2008 mit Änderungen vom 11. August 2010; Einspeisevergütung für im Kalenderjahr 2012 neu in Betrieb genommene Eigenerzeugungsanlagen nach dem Erneuerbare-Energien-Gesetz-EEG vom 28.07.2011

1. RR: Renewable Resources; 2. M: Manure; 3. LM: Landscaping Material; 4. ER: Emission Reduction; 5. FC I: Feedstock Class I; 6. FC II: Feedstock class II; 7. OW: Organic Waste; 8 . this category is specified for the small manure biogas plant 
Table 8 Results of variance inflation factor of independent variables for both Model I and II

\begin{tabular}{|c|c|c|c|}
\hline Environmental-social-economic variables & Variance inflation factor & Control and EEG dummy variables & $\begin{array}{l}\text { Variance } \\
\text { inflation } \\
\text { factor }\end{array}$ \\
\hline \multicolumn{4}{|c|}{ Model I.1:BP $=\ln (B P I)+\ln (A E)+\ln (D /)+\ln (G N)+\ln (L P)+\ln (P P A P)+$ City } \\
\hline $\ln (\mathrm{BPI})$ & 1.77 & City & 2.88 \\
\hline $\ln (\mathrm{AE})$ & 3.15 & $\mathrm{EEG}_{\|}$ & - \\
\hline $\ln (\mathrm{D} \mid)$ & 3.42 & $E E G_{\|}$ & - \\
\hline $\ln (G N)$ & 1.31 & EEG/V & - \\
\hline $\ln (L P)$ & 2.30 & & \\
\hline $\ln ($ PPAP) & 2.22 & & \\
\hline \multicolumn{4}{|c|}{ Model I.2: $\ln (I C)=\ln (B P I)+\ln (A E)+\ln (D /)+\ln (G N)+\ln (L P)+\ln (P P A P)+$ City } \\
\hline $\ln (\mathrm{BPI})$ & 1.16 & City & 1.54 \\
\hline $\ln (A E)$ & 2.63 & $\mathrm{EEG}_{\|}$ & - \\
\hline $\ln (\mathrm{DI})$ & 3.25 & $\mathrm{EEG}_{\|}$ & - \\
\hline $\ln (G N)$ & 1.08 & $\mathrm{EEG}_{\mathrm{IV}}$ & - \\
\hline $\ln (L P)$ & 1.21 & & \\
\hline $\ln ($ PPAP) & 1.81 & & \\
\hline \multicolumn{4}{|c|}{ Model II.1:BP $=\ln (B P I)+\ln (A E)+\ln (D /)+\ln (G N)+\ln (L P)+\ln (P P A P)+$ City $+E E G$} \\
\hline $\ln (\mathrm{BPI})$ & 1.81 & City & 3.09 \\
\hline $\ln (A E)$ & 3.74 & $\mathrm{EEG}_{\|}$ & 2.89 \\
\hline $\ln (\mathrm{DI})$ & 6.75 & $\mathrm{EEG}_{\|}$ & 5.12 \\
\hline $\ln (G N)$ & 1.39 & $\mathrm{EEG}_{\mid V}$ & 5.40 \\
\hline $\ln (L P)$ & 2.50 & & \\
\hline $\ln ($ PPAP) & 3.19 & & \\
\hline \multicolumn{4}{|c|}{ Model II.2: $\ln (I C)=\ln (B P I)+\ln (A E)+\ln (D /)+\ln (G N)+\ln (L P)+\ln (P P A P)+$ City $+E E G$} \\
\hline $\ln (\mathrm{BPI})$ & 1.20 & City & 1.70 \\
\hline $\ln (A E)$ & 3.14 & $\mathrm{EEG}_{\|}$ & 4.34 \\
\hline $\ln (\mathrm{D} \mid)$ & 5.21 & $E E G_{\| I}$ & 8.01 \\
\hline $\ln (G N)$ & 1.11 & $\mathrm{EEG}_{\mid V}$ & 5.13 \\
\hline $\ln (L P)$ & 1.32 & & \\
\hline In(PPAP) & 2.73 & & \\
\hline
\end{tabular}



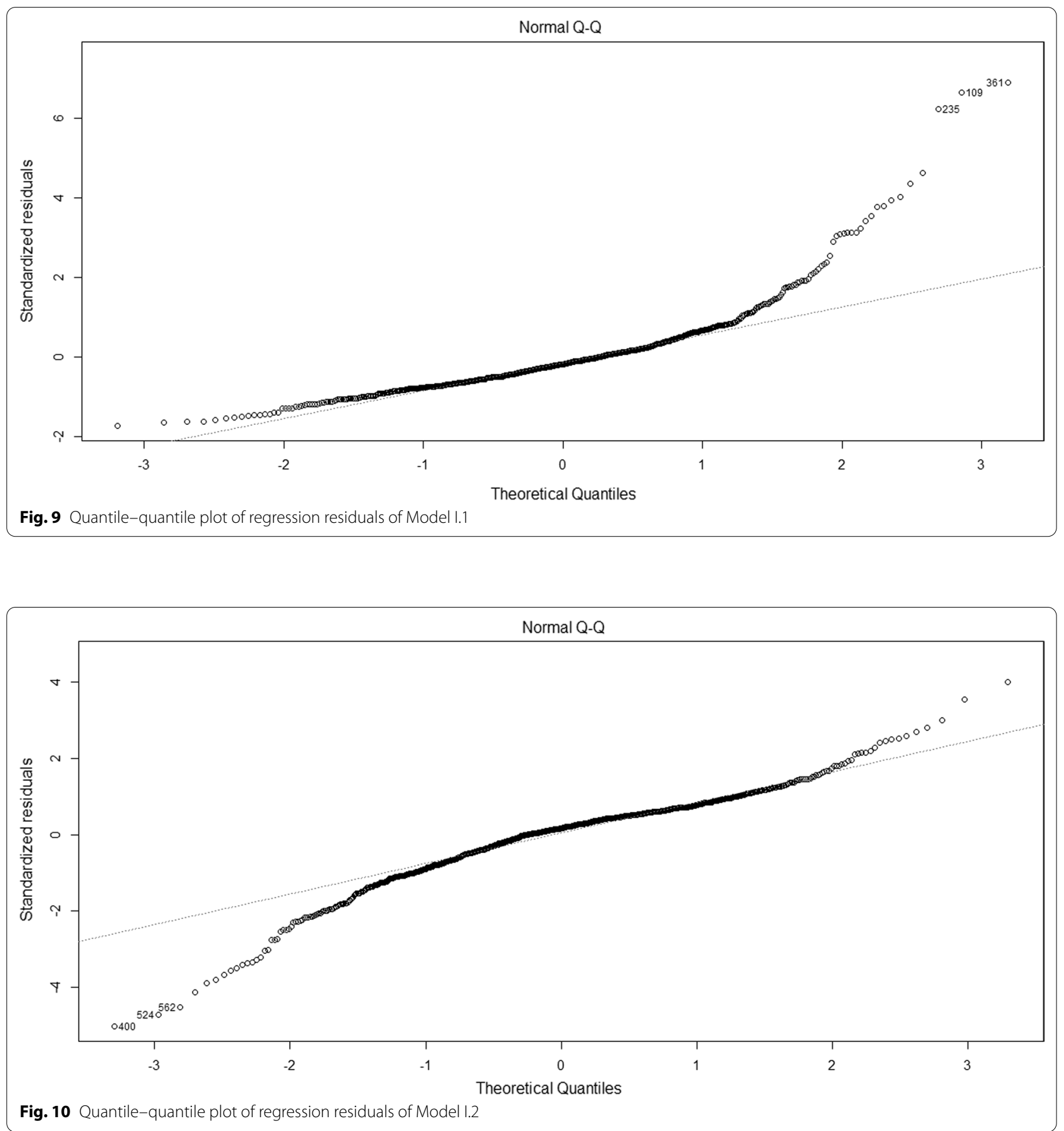


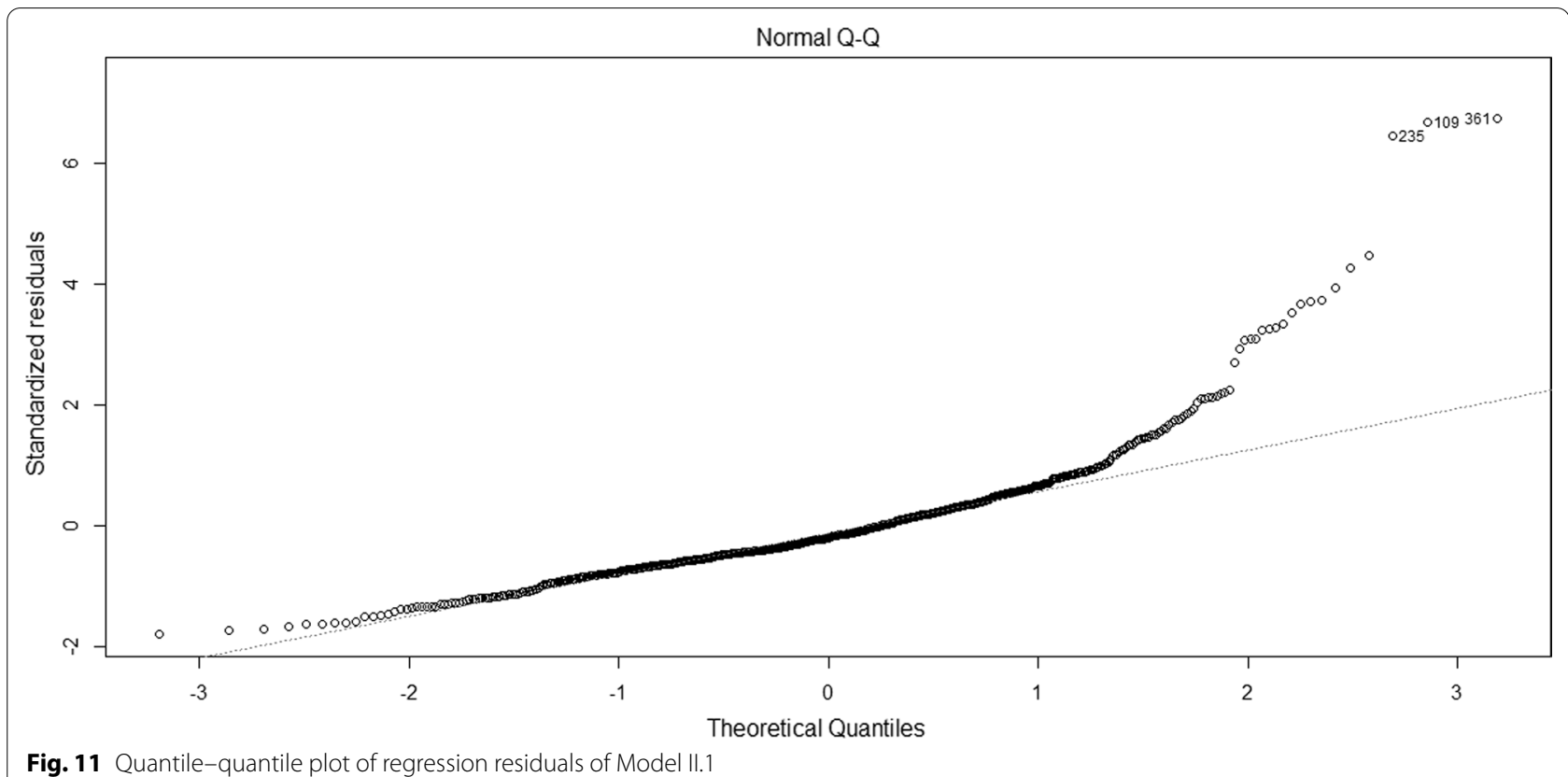

Fig. 11 Quantile-quantile plot of regression residuals of Model II.1

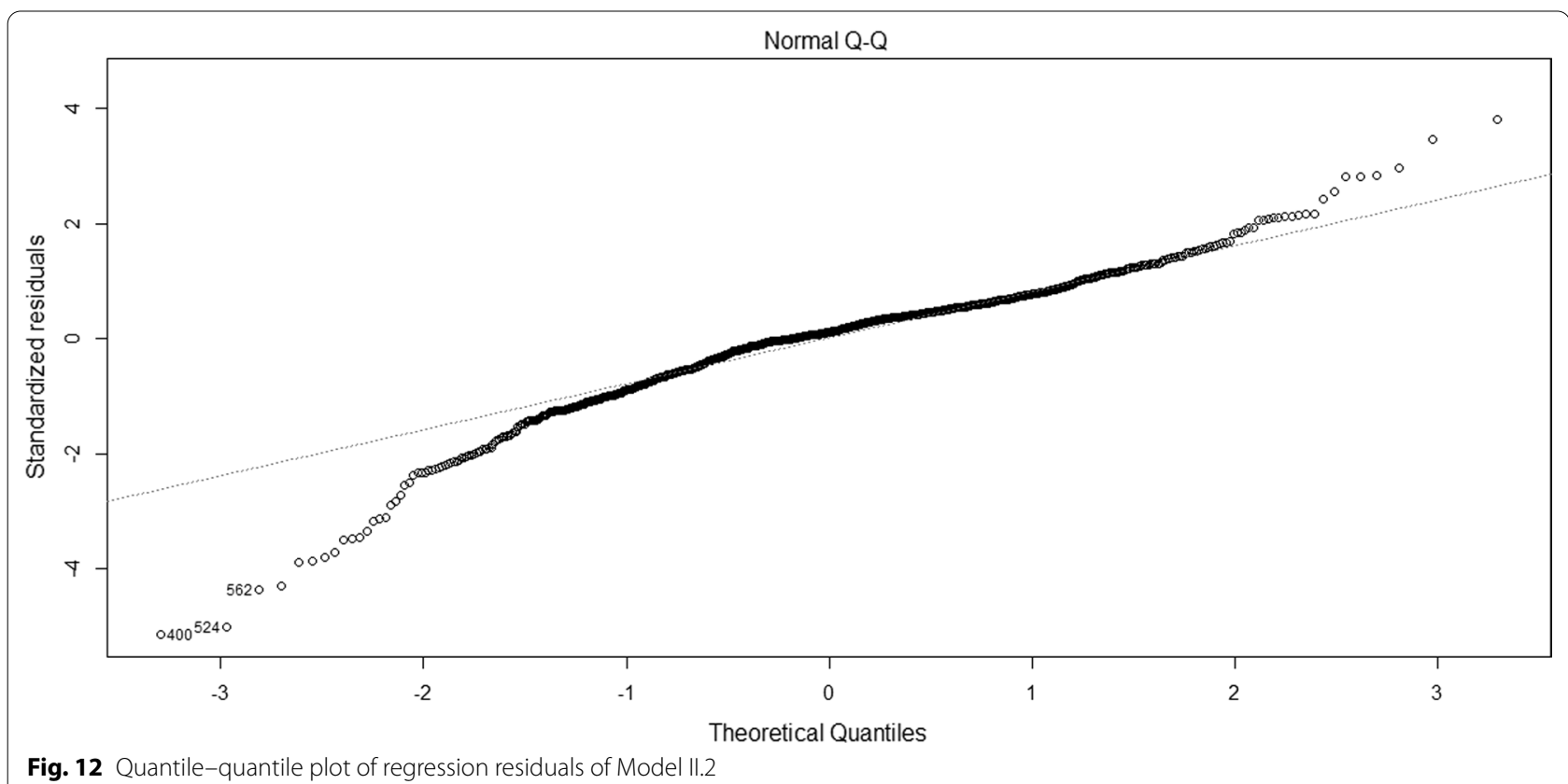




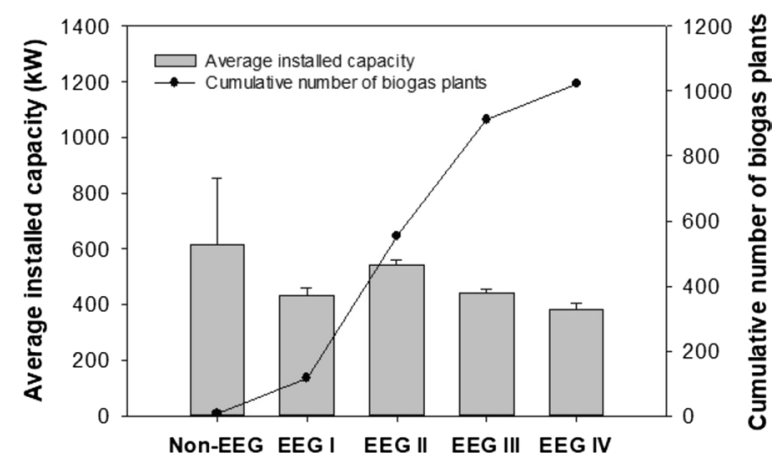

Fig. 13 Cumulative number of biogas plants from the Non-EEG to the EEG IV period and the average installed capacity in each period. Source: EE-Monitor

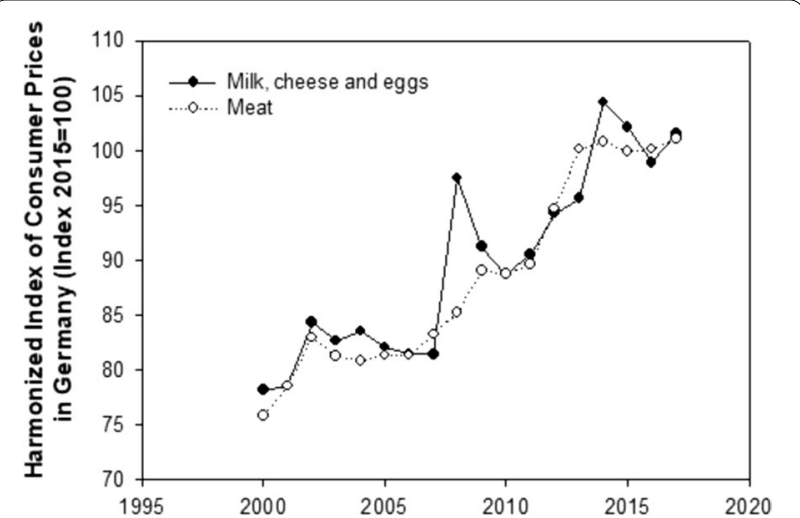

Fig. 14 The harmonized index of consumer prices for products like milk, cheese, eggs and meat in Germany (index $2015=100$ ) from 2000 to 2017. Source: Federal Reserve Bank of St. Louis

\section{Abbreviations}

EEG: Erneuerbare Energien Gesetz; CG: Central Germany; GIS: Geographic Information System; GHG: Greenhouse gas; FIT: Feed-in tariff; UTA: Utilized agricultural area.

\section{Acknowledgements}

We would like to thank David Manske for supporting us in the provision of spatial information on biogas plants and Dr. Norbert Kohlheb for providing valuable comments. We are also grateful to the anonymous reviewers for their constructive comments.

\section{Authors' contributions}

$X Y$ and $Y L$ designed the underlying model, analyzed the literature and interpreted the results. The empirical analysis section was mainly conducted by $Y L$. The spatial analysis section was mainly assessed by XY. The manuscript was written primarily by XY and YL. All authors contributed significant feedback for improving the overall manuscript. All authors read and approved the final manuscript.

\section{Funding}

Open Access funding enabled and organized by Projekt DEAL.

\section{Availability of data and materials}

As described in the "Methods" section, the raw data used for the study were collected from many different sources. Most of these are publicly available.
The datasets analyzed in the current study are available from the corresponding author upon reasonable request.

\section{Declarations}

\section{Ethics approval and consent to participate}

Not applicable.

\section{Consent for publication}

Not applicable.

\section{Competing interests}

The authors declare that they have no conflicting interests.

\section{Author details}

${ }^{1}$ Department of Bioenergy, Helmholtz-Centre for Environmental Research (UFZ), Permoserstrasse 15, 04318 Leipzig, Germany. ${ }^{2}$ Research Group "Macroecology and Society", German Center for Integrative Biodiversity Research (iDiv), Deutscher Platz 5e, 04103 Leipzig, Germany. ${ }^{3}$ Department of Bioenergy Systems, Deutsches Biomasseforschungszentrum Gemeinnützige $\mathrm{GmbH}$ DBFZ, Torgauer Strasse 116, 04347 Leipzig, Germany. ${ }^{4}$ Chair of Behavioral Finance, WHU-Otto Beisheim School of Management, Burgplatz 2, 56179 Vallendar, Germany.

Received: 18 August 2020 Accepted: 3 March 2021

Published online: 18 March 2021

\section{References}

1. UNFCCC (2015) The Paris Agreement. https://unfccc.int/process-andmeetings/the-paris-agreement/

2. 406/2009/EC Decision No 406/2009/EC of the European Parliament and of the Council of 23 April 2009 on the effort of Member States to reduce their greenhouse gas emissions to meet the Community's greenhouse gas emission reduction commitments up to 2020. Off J Eur Union: 136-148

3. BMU (2016) Climate Action Plan 2050: Principles and goals of the German government's climate policy 2016. Federal Ministry of the Environment Nature Conservation and Nuclear Safety,

4. IPCC (2014) Climate change 2014: Synthesis report. Contribution of working groups I, II and III to the Fifth Assessment Report of the Intergovernmental Panel on Climate Change. Geneva, Switzerland

5. Renn O, Marshall JP (2016) Coal, nuclear and renewable energy policies in Germany: from the 1950s to the "Energiewende." Energ Policy 99:224-232

6. Yu L, Xue B, Stückrad S, Thomas H, Cai GT (2020) Indicators for energy transition targets in China and Germany: a text analysis. Ecol Indic 111:106012

7. Fischedick M (2019) German energy transition-targets, current status, chances and challenges of an ambitious pathway. KORUM 80:6-9

8. Martin B (2010) 10 Years Renewable Energies Act (EEG)-looking back on a success story. German Biogas Association. https://www.kriegfisch er.de/fileadmin/images/news/International_EEG.pdf. Accessed 2 Nov 2020

9. Büsgen U, Dürrschmidt W (2009) The expansion of electricity generation from renewable energies in Germany: a review based on the Renewable Energy Sources Act Progress Report 2007 and the new German feed-in legislation. Energy Policy 37(7):2536-2545

10. Klaus T, Vollmer C, Werner K, Lehmann H, Müschen K (2010) Energy target 2050: 100\% renewable electricity supply. Federal Environment Agency Germany, Dessau-Roßlau

11. IEA (2020) Germany 2020 Energy policy review. International Energy Agency,

12. Sims REH, Hastings A, Schlamadinger B, Taylor G, Smith P (2006) Energy crops: current status and future prospects. Glob Change Biol 12(11):2054-2076. https://doi.org/10.1111/j.1365-2486.2006.01163.x

13. Daniel-Gromke J, Rensberg N, Denysenko V, Trommler M, Reinholz T, Völler K, Beil M, Beyrich W (2017) Anlagenbestand Biogas und 
Biomethan: Biogaserzeugung und -nutzung in Deutschland. DBFZReport, 30. DBFZ, Leipzig

14. FNR (2019) Bioenergy in Germany acts and figures Agency for Renewable Resources

15. Thrän D, Schaubach K, Majer S, Horschig T (2020) Governance of sustainability in the German biogas sector-adaptive management of the Renewable Energy Act between agriculture and the energy sector. Energy Sustain Soc. 10(3):1-18

16. EEG (2000) Renewable Energy Sources Act-EEG https://www.clearingst elle-eeg-kwkg.de/gesetz/4957

17. EEG (2004) Renewable Energy Sources Act-EEG. https://www.clear ingstelle-eeg-kwkg.de/eeg2004

18. EEG (2009) Renewable Energy Sources Act-EEG. https://www.clear ingstelle-eeg-kwkg.de/eeg2009

19. EEG (2012) Renewable Energy Sources Act-EEG https://www.clear ingstelle-eeg-kwkg.de/eeg2012

20. EEG (2014) Renewable Energy Sources Act-EEG https://www.clear ingstelle-eeg-kwkg.de/eeg2014

21. EEG (2017) Renewable Energy Sources Act-EEG. https://www.clear ingstelle-eeg-kwkg.de/eeg2017

22. Gomiero T (2018) Large-scale biofuels production: a possible threat to soil conservation and environmental services. Appl Soil Ecol 123:729-736

23. Delzeit R, Britz W, Kreins P (2012) An economic assessment of biogas production and land use under the German Renewable Energy Source Act. Kiel Working Papers 176. Kiel Institute for the World Economy (IFW)

24. Balussou D (2018) An analysis of current and future electricity production from biogas in Germany. Karlsruhe Institute of Technology (KIT), Germany

25. Herbes C, Jirka E, Braun JP, Pukall K (2014) The social discourse on the "Maize Cap" before and after the 2012 amendment of the German Renewable Energies Act (EEG). Gaia 23:100-108

26. Appel F, Ostermeyer-Wiethaup A, Balmann A (2016) Effects of the German Renewable Energy Act on structural change in agriculturethe case of biogas. Util Policy 41:172-182. https://doi.org/10.1016/j. jup.2016.02.013

27. Purkus A, Gawel E, Szarka N, Lauer M, Lenz V, Ortwein A, Tafarte P, Eichhorn M, Thrän D (2018) Contributions of flexible power generation from biomass to a secure and cost-effective electricity supplya review of potentials, incentives and obstacles in Germany. Energy Sustain Soc 8(1):18. https://doi.org/10.1186/s13705-018-0157-0

28. Lovrenčec $L$ (2010) Highlights of socio-economic impacts from biogas in 28 target regions RA Sinergija

29. von Bock und Polach C, Kunze C, Maaß O, Grundmann P (2015) Bioenergy as a socio-technical system: the nexus of rules, social capital and cooperation in the development of bioenergy villages in Germany. Energy Res. Soc. Sci. 6:128-135

30. Lebuhn M, Munk B, Effenberger M (2014) Agricultural biogas production in Germany - from practice to microbiology basics. Energy. Sustain Soc 4:1-21

31. Theuerl S, Herrmann C, Heiermann M, Grundmann P, Landwehr N, Kreidenweis U, Prochnow A (2019) The future agricultural biogas plant in Germany: a vision. Energies 12(396):1-32

32. Scheftelowitz M, Beck R, Thrän D (2018) Improved power provision from biomass: a retrospective on the impacts of German energy policy. Biomass Bioenerg. 111:1-12

33. Abbas T, Ali G, Adil SA, Bashir MK, Kamran MA (2017) Economic analysis of biogas adoption technology by rural farmers: the case of Faisalabad district in Pakistan. Renew Energy 107:431-439

34. Kabir H, Yegbemey RN, Bauer S (2013) Factors determinant of biogas adoption in Bangladesh. Renew Sust Energ Rev 28:881-889

35. Mwirigi JW, Makenzi PM, Ochola WO (2009) Socio-economic constraints to adoption and sustainability of biogas technology by farmers in Nakuru Districts, Kenya. Energy Sustain Dev 13(2):106-115

36. Sarker SA, Wang SY, Adnan KMM, Sattar MN (2020) Economic feasibility and determinants of biogas technology adoption: Evidence from Bangladesh. Energy Rev 123:10976

37. Mengistu MG, Simane B, Eshete G, Workneh TS (2016) Factors affecting households' decisions in biogas technology adoption, the case of Ofla and Mecha Districts, northern Ethiopia. Renew Energ 93:215-227
38. Momanyi RK, Ong'ayo AH, Benards O (2016) Social-economic factors influencing biogas technology adoption among households in Kilifi county—Kenya. J Energy Resour Technol 6:20-33

39. Eurostat (2020) Livestock: number of farms and heads of animals of different types by agricultural size of farm (UAA) and NUTS 2 regions. https://ec.europa.eu/eurostat/statistics-explained/index.php?title= Agricultural_census_in_Germany\&oldid=379544. Accessed Sep. 52020

40. Jan I, Akram W (2018) Willingness of rural communities to adopt biogas systems in Pakistan: critical factors and policy implications. Renew Sust Energ Rev 81:3178-3185

41. Adjakloe YDA, Osei SA, Boateng ENK, Agyapong F, Koranteng C, Baidoo ANA (2020) Household's awareness and willingness to use renewable energy: a study of Cape Coast Metropolis Ghana. Int J Sustain Energy. https://doi.org/10.1080/14786451.2020.1807551

42. Al-Marri W, Al-Habaibeh A, Watkins M (2018) An investigation into domestic energy consumption behaviour and public awareness of renewable energy in Qatar. Sustain Cities Soc 41:639-646

43. Kardooni R, Yusoff SB, Kari FB (2016) Renewable energy technology acceptance in Peninsular Malaysia. Energy Policy 88:1-10

44. Shen GF, Lin WW, Chen YC, Yue DL, Liu ZL, Yang CL (2015) Factors influencing the adoption and sustainable use of clean fuels and cookstoves in China-a Chinese literature review. Energy Rev 51:741-750

45. Bekchanov M, Mondal MAH, de Alwis A, Mirzabaev A (2019) Why adoption is slow despite promising potential of biogas technology for improving energy security and mitigating climate change in Sri Lanka? Energy Rev 105:378-390

46. Milos T, Ferenc K, Zoltan Z (2011) Renewable energy policy in the Republic of Serbia. Renew Sust Energ Rev 15(1):752-758

47. Kuzemko C (2019) Re-scaling IPE: local government, sustainable energy and change. Rev Int Polit Econ 26(1):80-103

48. Mans U, Meerow S (2012) Role of local governments in promoting renewable energy businesses: a contribution to the green urban economy. ICLEI Global Report. University of Amsterdam and ICLEI, Bonn

49. Walekhwa PN, Lars D, Mugisha D (2014) Economic viability of biogas energy production from family-sized digesters in Uganda. Biomass Bioenerg 70:26-39

50. Gibbons MR (1980) Econometric methods for testing a class of financial models: an application of the nonlinear multivariate regression model. University of Chicago, USA

51. Binder JJ (1983) Measuring the effects of regulation with stock price data: a new methodology. University of Chicago, Chicago

52. Philipp M, Römer D (2012) On the obligation to provide environmental information in the 21st century-empirical evidence from Germany. Discussion Paper Series No 524

53. Regionaldatabank. https://www.regionalstatistik.de/genesis/online/. Accessed 1 Feb 2020

54. Kothari SP, Warner JB (2007) Handbook of corporate finance, empirical corporate finance volume 1, Chapter 1, Econometrics of event studies The Netherlands

55. Binder JJ (1985) On the use of the multivariate regression model in event studies. J Account Res 23(1):370-383

56. Binder JJ (1985) Measuring the effects of regulation with stock price data. RAND J Econ 16(2):167-183

57. Mangel M, Samaniego FJ (1984) Abraham Wald's work on aircraft survivability. J Am Stat Assoc 79(386):259-267

58. Tsiotsou R, Lalountas D (2005) Applying event study analysis to assess the impact of marketing communication strategies: the case of sponsorship. Appl Econ Lett 1:259-262

59. Chambers JM (1992) Linear models. Chapter 4 of statistical models in S. Hastie: Wadsworth \& Brooks/Cole

60. Walekhwa PN, Mugisha J, Drake L (2009) Biogas energy from familysized digesters in Uganda: critical factors and policy implications. Energy Policy 37:2754-2762

61. Shallo L, Ayele M, Sime G (2020) Determinants of biogas technology adoption in southern Ethiopia. Energy Sustain Soc. https://doi.org/10. 1186/s13705-019-0236-X

62. EE-Monitor (2018) POF3-Y1 - Renewable energy and material resources for sustainable futures-EE-Monitor. https://www.ufz.de/record/dmp/ archive/5368/de/. Accessed 4 Oct. 2019

63. Das S, Eichhorn M, Hoffgarten vM, Lang E, Priess JA, Thrän D (2012) Spatial analysis of the potential of district heating from existing bioenergy 
installations in Germany. Paper presented at the 20th European Biomass Conference and Exhibition, Italy

64. Sachsen Statistisches Landesamt Sachsen. https://www.statistik.sachs en.de/

65. Sachsen-Anhalt Statistisches Landesamt Sachsen-Anhalt. https://stati stik.sachsen-anhalt.de/. Accessed 1 Jan 2020

66. TLS Thüringer Landesamt für Statistik. https://statistik.thueringen.de/

67. FNR Faustzahlen. https://biogas.fnr.de/daten-und-fakten/faustzahlen/. Accessed 30 Jan. 2020

68. DBFZ DBFZ Reports. https://www.dbfz.de/pressemediathek/publikatio nsreihen-des-dbfz/dbfz-reports/. Accessed 20 Nov. 2019

69. Statistiches-Bundesamt Price indices for agriculture and forestry. https://www.destatis.de/EN/Themes/Economy/Prices/Price-Indices-InAgriculture-And-Forestry/_node.html. Accessed 17 Feb 2020

70. Igliński B, Buczkowski R, Iglińska A, Cichosz M, Piechota G, Kujawski W (2012) Agricultural biogas plants in Poland: investment process, economical and environmental aspects, biogas potential. Renew Sust Energ Rev 16:4890-4900

71. Scarlat N, Fahl F, Dallemand J-F, Monforti F, Motola V (2018) A spatial analysis of biogas potential from manure in Europe. Renew Sust Energ Rev 94:915-930

72. Budzianowski WM, Chasiak I (2011) The expansion of biogas fuelled power plants in Germany during the 2001-2010 decade: Main sustainable conclusions for Poland. J Power Technol 91(2):102-113

73. Abdeshahian P, Lim JS, Ho WS, Hashim H, Lee CT (2016) Potential of biogas production from farm animal waste in Malaysia. Renew Sust Energ Rev 60:714-723

74. Thiering J (2010) Förderung der Biogasproduktion in Deutschland Rahmenbedingungen, Folgen und alternative Gestaltungsmöglichkeiten unter besonderer Berücksichtigung der Wirtschaftsdüngernutzung. Dissertation, Georg-August-Universität Göttingen, Göttingen, Deutschland

75. Csikos N, Schwanebeck M, Kuhwald M, Szilassi P, Duttmann R (2019) Density of biogas power plants as an indicator of bioenergy generated transformation of agricultural landscapes. Sustainability 11:1-23

76. Demartini E, Gaviglio A, Gelati M, Cavicchioli D (2016) The effect of biogas production on farmland rental prices: empirical evidences from Northern Italy. Energies 9(11):965

77. Goebel J, Krekel C, Tiefenbach T, Ziebarth NR (2015) How natural disasters can affect environmental concerns, risk aversion, and even politics: evidence from Fukushima and three European countries. J Popul Econ 28:1137-1180

78. Fuchs C, Bogatov V, Eimannsberger J Competitiveness and risk of crop production, milk production and biogas production with respect to regional resources. 18th International Farm Management Congress, Methven, Canterbury, New Zealand, ate 2011. pp 133-144

79. Schaper C, Beitzen-Heineke C, Theuvsen L (2008) Finanzierung und Organisation landwirtschaftlicher Biogasanlagen: Eine empirische Untersuchung. Journal of Socio-Economics in Agriculture (Until 2015: Yearbook of Socioeconomics in Agriculture) 1(1): 39-74

80. Singh KJ, Sooch SS (2004) Comparative study of economics of different models of family size biogas plants for state of Punjab. India Energy Convers Manag 45(9-10):1329-1341

81. ECB (2016) Savings and investment behaviour in the euro area. Occasional Paper Series

82. Laird FN, Stefes C (2009) The diverging paths of German and United States policies for renewable energy: sources of difference. Energy Policy 37(7):2619-2629

83. Lauber V, Mez L (2004) Three decades of renewable electricity policies in Germany. Energy Environ 15(4):599-623

84. Emmann $\mathrm{CH}$, Guenther-Lübbers W, Theuvsen L (2013) Impacts of biogas production on the production factors land and labour-current effects, possible consequences and further research needs. Int J Food Syst Dyn 4(1):1-13

85. Silke $H$, Martin O, Karin K, Alfons B (2013) Price formation on land market auctions in East Germany — an empirical analysis. German J Agric Econ 62(2):1-17

86. Myrna O, Odening M, Ritter M (2019) The influence of wind energy and biogas on farmland prices. Land 8(1):19. https://doi.org/10.3390/land8 010019
87. Hennig S, Latacz-Lohmann U (2017) The incidence of biogas feed-in tariffs on farmland rental rates-evidence from northern Germany. Eur Rev Agric Econ 44(2):231-254

88. Appel F, Ostermeyer-Wiethaup A, Balmann A (2016) Effects of the German Renewable Energy Act on structural change in agriculture-the case of biogas. Utilities Policy 41:172-182

89. World B. https://www.biogasworld.com/. Accessed 12 April 2020

90. Vatcheva KP, Lee MJ, McCormick JB, Rahbar MH (2016) Multicollinearity in regression analyses conducted in Epidemiologic studies. Epidemiol 6(227):1-9

91. Eurostat (2019) NUTS 2016. https://ec.europa.eu/eurostat/web/gisco/ geodata/reference-data/administrative-units-statistical-units/nuts. Accessed 20 March 2020

92. Fischer T, Krieg A, Chae KJ, Yim SK, Choi KH, Park WK, Eom KC (2002) Farm-scale biogas plants. J Korea Org Resour Recycl Assoc 9:136-144

93. Ruth D, Ulla K (2011) How location decisions influence transport costs of processed and unprocessed bioenergy digestates: The impact of plant size and location on profitability of biogas plants in Germany. Kiel Working Papers 1730, Kiel Institute for the World Economy

94. Amigun B, von Blottnitz H (2010) Capacity-cost and location-cost analyses for biogas plants in Africa. Resour Conserv Recycl 55(1):63-73

95. Daniel-Gromke J, Rensberg N, Denysenko V, Stinner W, Schmalfuß T, Scheftelowitz M, Nelles M, Liebetrau J (2018) Current developments in production and utilization of biogas and biomethane in Germany. Chem Ing Tech 90:17-35

96. Eyl-Mazzega M, Mathieu C (2019) Biogas and biomethane in Europe: lessons from Denmark, Germany and Italy. The Institut français des relations internationales (Ifri)

97. Balussou D, McKenna R, Möst D, Fichtner W (2018) A model-based analysis of the future capacity expansion for German biogas plants under different legal frameworks. Renew Sust Energ Rev 96:119-131

98. Vergara F, Lakes T (2019) Maizification of the landscape for biogas production? Identifying the likelihood of silage maize for Biogas in Brandenburg from 2008-2018. FORLand-Working Paper 16. Berlin

99. Barobot YN (2014) Biogas from marine macroalgal waste. Jacobs University Bremen, Bremen

100. Lagger B, Orthen N, Osterburg B, Röder N (2014) Ist die zunehmende Biogasproduktion die alleinige Ursache für den Grünlandschwund in Deutschland? - eine Analyse von georeferenzierten Daten zur Landnutzung. RuR 72(3):195-209

101. Lüker-Jans N, Simmering D, Otte A (2017) The impact of biogas plants on regional dynamics of permanent grassland and maize area-the example of Hesse, Germany (2005-2010). Agric Ecosyst Environ 241:24-38

102. BfN (2015) Losses of/gains in grassland in Germany between 1999 and 2013, by state. Federal Agency for Nature Conservation. https://www. bfn.de/en/service/facts-and-figures/the-utilisation-of-nature/agric ulture/loss-of-valuable-grassland.html. Accessed 20 Apr. 2020

103. Duttmann R, Schwanebeck M, Csikos N (2019) Landschafts- und Umweltwirksamkeit der Biogasproduktion in Schleswig-Holstein. Berichte Geographie und Landeskunde (BGL) 92(1):1-96

104. Ostermeyer A, Balmann A Perception of dairy farming from different views - results of a stakeholder discussion in the region Altmark, Germany. Paper prepared for presentation at the EAAE 2011 Congress: change and uncertainty; challenges for agriculture, food and natural resources, Zurich, Switzerland, ate 2011.

105. EU-Council (2013) Reform of the common agricultural policy post 2013 https://www.consilium.europa.eu/en/policies/cap-reform/. Accessed 20 Apr 2020

106. BfN (2018) Grassland conservation in Germany. https://www.bfn.de/en/ activities/agriculture/grassland-conservation-in-germany.html\#c1549 39. Accessed 2 Jan 2020

\section{Publisher's Note}

Springer Nature remains neutral with regard to jurisdictional claims in published maps and institutional affiliations. 